\title{
DO LABORATÓRIO AO SISTEMA DE LABORATÓRIO: A PRODUÇÃO SOCIAL HUMANA NO SÉCULO XX-XXI E SUA POSSIBILIDADE INVESTIGATIVA NA EDUCAÇÃO
}

\section{FROM THE LABORATORY TO THE LABORATORY SYSTEM: THE HUMAN SOCIAL PRODUCTION IN THE XX-XXI CENTURY ON EDUCATION}

Samya Campana ${ }^{1 *}$

\begin{abstract}
Resumo
Baseados numa leitura crítica do modo como os homens transformam a realidade - pela união dos homens para reproduzir e produzir os meios de produção e suas vidas a partir de condições já existentes - discorremos sobre a ontologia da produção da ciência no século XX-XXI e sobre sua possibilidade investigativa na Educação entendendo-a como expressão orgânica (contraditória e em movimento) da superação das condições burguesas atualmente postas. Nosso ponto de partida e ao mesmo tempo resultado (item 1- "O sistema de laboratório: em busca da transcendência da sociabilidade da união entre os homens") é o que se convencionou chamar de nanociência, adotando como pressuposto dessa produção a criação dos homens que nos precederam na forma da grande indústria moderna do século XIX, despojando-a de seu caráter natural e submetendo-a ao poder dos indivíduos unidos, os quais explicitam e desenvolvem a constituição do ser social. Na segunda parte deste artigo (item 2 "Possibilidade de investigação na Educação no século XXI") formulamos uma questão de pesquisa para a Educação problematizando sua relação com essa nova forma produtiva laboratorial como afirmação, negação e superação da relação social burguesa de produção.
\end{abstract}

Palavras-Chaves: Laboratório - Ciência - Educação - Nano - Ontologia

\begin{abstract}
Based on a critical reading in a way that men transform the reality - by men union to reproduce and produce the production means and their lives from the existing conditions - it is discoursed on the science production ontology in the XX-XXI century and its investigative possibility in Education to understand it as organic expression (contradictory and in movement) of overcoming the bourgeois conditions nowadays. The standpoint and, at the same time, result (item 1 - "The laboratory system: searching for union sociality transcendence among the men") are what was agreed to call the nanoscience, adopting as presuppose of this production the creation of men that proceeded us in a big modern industry way of the XIX century, despoiling it from its natural character and submitting it to the united individual power which explicit and develop the social being constitution. On the second part of this paper (item 2 - "Investigation possibility on Education in the XXI century") is formulated a research question for Education troubling its relation with this new laboratorial productive way as statement, denial and surpass of the bourgeois social relationships of production.
\end{abstract}

Key-Words: Laboratory - Science - Education - Nano - Ontology 
1 O SISTEMA DE LABORATÓRIO: EM BUSCA DA TRANSCENDÊNCIA DA SOCIABILIDADE DA UNIÃO ENTRE OS HOMENS

É quase impossível encontrar algum tipo de trabalho científico em física ou química - da física do átomo à química orgânica estrutural - que mais cedo ou mais tarde não vá ter aplicações e importância direta para as indústrias. Trabalhos de pesquisa fundamental como esses requerem laboratórios diferentes dos laboratórios usuais de trabalho e pesquisadores diferentes daqueles empregados num laboratório puramente industrial. Significam um laboratório grande, equipado com esmero e com equipe de peso, empenhada por muitos anos em trabalho que não trará remuneração e que, por um tempo considerável, não chegará a nenhum resultado que possa ser aplicado pelo fabricante. $O$ valor de tal laboratório será cumulativo, à medida que 0 trabalho continua. A princípio, ele será útil para a indústria por trazer novos pontos de vista sobre muitos dos seus problemas. (Mees, 1920)

Nada de lo que fabricamos los humanos puede prescindir de los descubrimientos que se hacen hoy en los laboratorios. Las consecuencias a largo plazo de la nanotecnología serán verdaderamente transformadoras, el problema es que no se pueden predecir los detalles de esa transformación del mundo. (Thomas Theis, jefe de investigación de la corporación IBM, en The Washington Post, 22 de febrero de 2004)

O emprego do sistema de laboratório por parte do capital, assim como o emprego do laboratório agregado a um sistema de produção orgânico de máquinas, "[...] como qualquer outro desenvolvimento da força produtiva, tem por fim baratear as mercadorias, encurtar a parte do dia de trabalho da qual precisa o trabalhador para si mesmo, para ampliar a outra parte que ele dá gratuitamente ao capitalista". O sistema de laboratório serve para que se produza mais-valia, ao mesmo tempo que é um meio civilizado de desenvolvimento humano. Assim, "revela-se, de um lado, progresso histórico e fator necessário do desenvolvimento econômico da sociedade e, de outro, meio civilizado e refinado de exploração" (MARX, 1996, p.417-418).

Quais são os elementos que constituem a base material configurando as forças produtivas atualmente? É preciso considerar o significado o que os homens produzem (CAMPANA, 2006). Seguindo o raciocínio de Marx (1996, p.424), "na manufatura, o ponto 7de partida para revolucionar o modo de produção é a força de trabalho, na indústria moderna, o instrumental de trabalho", do que inferimos que, no sistema de laboratório, o ponto de partida que revoluciona o modo de produção é o objeto a que se aplica o trabalho, bem como o caráter teleológico desse ato histórico. Se a manufatura produz a decomposição do trabalho artesanal, e a maquinaria a 
decomposição dos meios de produção, pesquisaremos como o sistema de laboratório produz a decomposição do objeto sobre o qual se trabalha. Portanto, convém investigar como o objeto a que se aplica o trabalho a) é transformado, primeiro, mediante a impressão da forma exterior adequada à matéria utilizada e como, b) num segundo momento, é transformado mediante a alteração da estrutura interna da matéria.

A previsão de Richard Feynman, feita em 1959, de que seria possível colocar todo o conteúdo da Enciclopédia Britânica no espaço de uma cabeça de alfinete não propôs discutir como fazer, mas o que era possível de acordo com as leis da física; tampouco imaginou a revolução do século XXI com os princípios da mecânica clássica, a partir dos quais o processo de produção constitui operações que visam imprimir uma forma exterior adequada à matéria utilizada. Seu artigo sugere a produção com base no reordenamento de átomos e moléculas, procedimento que se assenta muito mais sobre parâmetros quânticos (FEYNMAN, 1959).

Hoje os homens produzem mediante a nanociência, que consiste em ciências e técnicas dirigidas a) ao estudo, desenho, criação, síntese, manipulação e aplicação de materiais, aparatos e sistemas funcionais através do controle da matéria à nano escala ${ }^{2}$ e b) à exploração de fenômenos e propriedades da matéria à nano escala, que se demonstram totalmente novos. Quando se fala de pesquisas envolvendo nanotecnologia, geralmente se distinguem os objetos de estudo, as técnicas utilizadas e os diferentes produtos que serão gerados (nanomagnetismo, metais ultrafinos, drogas nanocristalinas, nanofibras poliméricas e outros). Essas pesquisas agregam práticas e métodos não somente das várias áreas das ciências naturais, mas também destas com as das ciências formais. Em função disso, existe uma diversidade de idéias sobre o que é o fazer científico nos diferentes campos da nanotecnologia, reflexo do próprio modo de fazer ciência nas diferentes áreas.

As técnicas (procedimentos, processos, equipamentos e instrumentos) das várias áreas da ciência permitem três abordagens distintas para as nanotecnologias: a) abordagem, de cima para baixo, que consiste na construção de dispositivos por desbaste de materiais macroscópicos; b) construção de dispositivos que se formam espontaneamente a partir de componentes moleculares e c) manipulação de materiais 
átomo a átomo. A primeira abordagem é a utilizada em microeletrônica para produzir chips de computadores e mais recentemente para produzir testes clínicos em miniatura. A segunda abordagem recorre às técnicas de química e das ciências dos materiais. A terceira é a que requer um controle fino da matéria.

A primeira abordagem, oriunda da eletrônica, um dos ramos da física, estuda os fenômenos das cargas elétricas elementares, as propriedades e o comportamento dos elétrons, fótons, partículas elementares e ondas eletromagnéticas. Em geral desenvolve e estuda os circuitos eletrônicos e os seus componentes: o diodo, o transistor, o circuito integrado, a fotocélula, os microcircuitos, memória eletrônica, os microprocessadores, capacitores, indutores, resistores, entre outros. Chama atenção que há pouco mais de cinqüenta anos a maioria dos instrumentos eletrônicos ainda funcionava com válvulas termiônicas, parecidas com lâmpadas, geralmente barulhentas e problemáticas.

A segunda abordagem, advinda da química, envolve o estudo das transformações da matéria em oposição à física, que é o estudo de seus estados. É a ciência que trata das substâncias da natureza, dos elementos que a constituem, de suas características, de suas propriedades combinatórias, de processos de obtenção, de suas aplicações e de sua identificação. Descreve a maneira como os elementos se juntam e reagem entre si e a energia desprendida ou absorvida durante essas transformações.

No que diz respeito à terceira abordagem, a visualização e manipulação de átomos já é possível desde que Binnig e Rohrer (Prêmio Nobel, 1986) inventaram técnicas de varredura de sonda. ${ }^{3}$ "Os cientistas agora estão preocupados em saber como se comporta uma única molécula, como um elétron passa através dela e como construir um dispositivo eletrônico que movimenta um único elétron para armazenar informações e fazer computação" [sublinhado nosso] (TOMA, 2005).

As duas primeiras abordagens, historicamente, se desenvolveram diante da necessidade da decomposição histórica do conhecimento das forças motrizes e das formas de transmissão (formas já independentes, inteiramente livres dos limites da força humana), as quais transmitem movimento à máquina-ferramenta-automática que se apodera do objeto do ponto de vista atômico e/ou molecular e o altera de acordo 
com o fim desejado. É desse último elemento da produção automatizada, ou seja, a máquina-ferramenta-automática que age no objeto atômica/molecularmente, que parte a terceira abordagem, a essência da revolução científica iniciada em fins do século XIX. E essa máquina-ferramenta-automática continua a servir de ponto de partida sempre que se trata de transformar (aufhebung) o processo por inteiro - que já é examinado objetivamente em si mesmo - e suas fases componentes, levando a cabo cada um dos processos parciais e os entrelaçando por meio da ciência, do general intellect, do produto do desenvolvimento histórico geral em sua quinta-essência abstrata.

\subsection{A MÁQUINA-FERRAMENTA AUTOMÁTICA DE PRECISÃO QUÂNTICA}

Os procedimentos, processos, equipamentos e instrumentos com que trabalhavam o técnico-mecânico da manufatura e o engenheiro da grande indústria moderna, reaparecem na máquina-ferramenta-automática de precisão quântica de modo muito geral, embora muitas vezes de forma modificada ${ }^{4}$, pois não é norteada à forma exterior do objeto (sendo o processo constituído por operações que visam imprimir uma forma exterior adequada à matéria utilizada através de princípios clássicos), mas à forma interior do objeto: o processo, comportando uma explicação quântica, é feito de operações que visam a alteração da estrutura interna da matéria. $O$ fazer atômico e molecular, em si, não comporta uma explicação somente por princípios clássicos, mas, essencialmente, por princípios quânticos.

A diferença entre a máquina-ferramenta-automática que comporta a explicação clássica e o corpo da máquina-ferramenta-automática que comporta a explicação quântica, na qual a primeira se engasta, vem da construção originária.

A primeira ainda é produzida pela cooperação de muitas máquinas e/ou pelo sistema orgânico de máquinas (algumas partes são produzidas por um sistema manufatureiro), que comporta os princípios clássicos, sendo depois associada ao corpo da máquina-ferramenta-automática de precisão atômica e/ou molecular.

A segunda, por sua vez, é essencialmente oriunda de uma produção automatizada que comporta a explicação de princípios quânticos: é um sistema que, ao Ihe ser transmitido força motriz e transmissão apropriados, age, baseado em princípios quânticos, sobre o objeto, a partir do conhecimento de sua estrutura atômica, molecular 
- o que antes, e dentro do limite de não se conhecer a estrutura interna da matéria, era realizado pela incursão da máquina automática embasada em princípios clássicos. ${ }^{5} \mathrm{~A}$ força motriz (ou mesmo as partes componentes de transmissão) prover de outra máquina automática cujos princípios firmados sejam clássicos não muda a essência desse processo produtivo. Quando a produção automatizada, baseada nos princípios clássicos, incide sobre a forma exterior do objeto (a ponto de evidenciar seus limites em explicar os elementos componentes da matéria constitutivos ao objeto), os princípios quânticos tomam o lugar dos princípios clássicos. A diferença quanto ao modo de agir no objeto salta aos olhos, mesmo quando a produção da força motriz e da transmissão - tanto no sentido da força motriz para a máquina-ferramenta-automática como no sentido desta última em relação ao objeto - opera mediante os princípios clássicos. A partir desse momento, independentemente do avanço dos princípios clássicos (por exemplo, do número e qualidade de máquina-ferramenta-automática que opera 0 objeto), o raio de sua ação passa a ser limitado, pois se visa sempre a forma exterior do objeto. Desse modo, o fazer atômico e/ou molecular do objeto, que comporta princípios quânticos, se emancipa da barreira orgânica que a máquina-ferramenta-automática de transformação da forma exterior do objeto, de incursão clássica, não podia ultrapassar.

A máquina-ferramenta-automática que comporta a explicação de princípios quânticos põe em evidência a distinção que há entre duas funções da máquina automática norteada pela explicação de princípios clássicos: a) função de operar a forma exterior do objeto e b) função de força motriz e forma de transmissão. A explicação por meio de princípios quânticos se expressou nessa primeira função do sistema automatizado. Por sua vez, a relacionada aos princípios clássicos se expressou mediante o aprimoramento da função automática relacionada à força motriz e à transmissão (ao lado do trabalho de vigiar a máquina e corrigir seus erros por meio de outras máquinas e/ou ainda das próprias mãos humanas). Por outro lado, a decomposição da primeira parte do sistema automatizado - as máquinas motrizes e os meios de transmissão -, pelo laboratório, deu origem a novos conhecimentos. Assim, apesar de as máquinas motrizes terem se transformado em máquinas elétricas, em parte no final do século XIX e inclusive antes, ainda que esporadicamente, não foi isso que revolucionou o modo de produção. Posteriormente se tornou claro que, mesmo na 
sua forma automatizada, essas máquinas, antes acionadas pelo vapor das caldeiras de máquinas térmicas em função da queima do carvão, passaram a ser acionadas por máquinas elétricas (geradores) - impulsionadas pela queima de derivados do petróleo e turbinas a vapor. Foi somente a utilização do petróleo como combustível que permitiu a humanização desse invento, possibilitando obter energia elétrica em grandes quantidades, pois a combustão de derivados do petróleo tem alto poder calorífico (ESTAÇÃO CIÊNCIA, 2005). A própria descoberta da corrente e da baterias elétrica (por Volta, em 1800) considerando-se os 70 anos que se seguiram à invenção não provocou nenhuma revolução industrial. ${ }^{6}$ Ao contrário, foi a construção de um sistema automatizado de máquina-ferramenta-automática que "fazia fenômenos" que não eram explicados pela física clássica que tornou necessária e possível uma revolução nas forças motrizes e nas formas de transmissão - ocasionando, inclusive, um novo conceito de fábrica (taylorista-fordista). Somente assim se explica o salto da física clássica para a física quântica como determinação essencial da forma como os homens produzem a existência, bem como a reconfiguração (transformação) da primeira pela segunda. ${ }^{7}$ Quando os princípios clássicos passaram a atuar apenas como força motriz e transmissão no sistema de máquinas, deixando de atuar junto da máquinaferramenta-automática que atua sobre o objeto - visto que a transformação exterior do objeto já tinha alcançado seu limite histórico -, os princípios quânticos tomaram seu lugar. Essa mudança dá origem a grandes modificações técnicas no sistema automático, construído somente para ser impulsionado pelos princípios clássicos. Hoje, todas as máquinas que têm de se impor como transformadoras da matéria são construídas se considerando, fundamentalmente, os princípios quânticos, sempre que sua própria natureza e finalidade não impeçam que sejam utilizadas em tamanho pequeno. É desse modo que se transmuta a grande indústria, na medida em que passa a ser determinada pelo sistema de laboratório.

Assim, a revolução científica, guiada pelos princípios quânticos, tem como ponto de partida um sistema de máquina automática que opera com vários tipos de máquinas e é acionado por vários tipos de força motriz, sendo que essa junção é capaz de trabalhar o objeto microscopicamente. O laboratório, por meio dos conhecimentos clássicos sobre a mecânica, ótica, termodinâmica e eletromagnetismo, passou a 
observar fenômenos inexplicáveis (pela ótica dos próprios parâmetros clássicos) que, apesar de "descobertos" pelos princípios que as geraram, apontaram para uma direção diametralmente oposta, negando-os. Temos, então, o laboratório, mas ainda como elemento simples da produção automatizada ${ }^{8}$. O laboratório é, historicamente, engendrado como uma necessidade da grande indústria, mas, enquanto esteve dependente e preso à máquina-ferramenta-automática baseada em princípios clássicos, não conseguiu constituir nova força produtiva.

As leis de Newton para a mecânica e gravitação vinham sendo aperfeiçoadas desde o século XVII e descreviam, com grande precisão, o comportamento dos corpos celestes e terrestres. Por outro lado, as propriedades elétricas e magnéticas haviam sido unificadas após o final de 1880 na teoria eletromagnética por James Maxwell. Entretanto, muitas das observações experimentais feitas no século XIX relacionadas à dinâmica de sistemas microscópicos - como grandes moléculas - só eram aproximadas pela mecânica clássica. ${ }^{9}$ Buscando, teleologicamente, maior precisão das novas observações, os homens diminuiram o tamanho das máquina-ferramenta-automática e aperfeiçoaram e diminuiram os componentes com que a operavam, o que exigiu, ao mesmo tempo, força motriz e formas de transmissão mais potentes, porém adequadas à diminuição: para vencer a limitação precisaram de uma força motriz superior à utilização da máquina a vapor (e a carvão), objetivada em usinas elétricas (geradores) e no petróleo. Desse modo, o transporte da máquina a vapor se mostrou impossível a longas distâncias, ou realizável com tecnologias ineficazes e, ao mesmo tempo, perigosas (cabos mecânicos, redes de água sob pressão ou de ar comprimido de vapor e de gás). O menor tamanho e maior potência dos motores elétricos entraram em conflito com os mecanismos de transmissão, de modo que as "descobertas", no século XIX, no campo do eletromagnetismo, resgataram a emissão termiônica ou eletrônica por T. Edison (em 1884) e tornaram possível e necessária sua aplicação através da válvula de dois eletrodos aprimorada por Lee de Forest (em 1907) (ao introduzir um novo elemento e empregá-la com êxito nas transmissões de telegrafia sem fios). Aperfeiçoando a válvula diodo, inventada por Fleming poucos anos antes, Forest construiu o primeiro dispositivo eletrônico capaz de amplificar tensões elétricas. Com a utilização prática para a 
emissão termiônica, através da utilização do diodo termoiônico, tríodos, tetrodos, pentodos, etc., se iniciou a era da eletrônica termiônica, ou termiônica. Do mesmo modo, a fragilidade desse tipo de mecanismo de transmissão, evidenciada nas duas Guerras Mundiais, e os avanços dele decorrentes conduziram ao transistor, facilitador da miniatuarização eletrônica. Desse modo, a grande indústria, ao se desenvolver por meio do laboratório, engendrou a constituição do novo: o sistema de laboratório, no século XX.

Há mais de dois mil anos, os filósofos gregos Leucipo e Demócrito especularam que a matéria era constituída de partículas indivisíveis que eles denominaram átomos. Entretanto, somente no século $\mathrm{XX}$, a existência dos átomos foi comprovada com bases científicas, social e universalmente para todos os homens, quando vários experimentos demonstraram que os átomos apresentam uma estrutura que pode ser modificada por ações exteriores (a despeito do fato de que no final do século XIX, já ter sido confirmada a existência de partículas menores do que o átomo, sem se saber, contudo, sua relação com o próprio átomo). Por isso os problemas teóricos com que se deparavam os homens e a ciência, no final do século XIX, se relacionaram com a estrutura da matéria, sendo causais (MARTINS, 2005). Antes disso, a matéria não constituía um problema causal da produção da existência dos homens, sendo apenas um problema casual (FERRAZ NETO, sd).

O modelo atômico de Thomson ${ }^{10}$, até então prevalecente, foi refutado, originalmente, e aperfeiçoado pela experiência de Rutherford, que utilizou um feixe de partículas alfa, emitido por polônio radioativo, sobre uma folha fina de ouro. Ele constatou que a maioria das partículas atravessava a placa sem sofrer alteração em sua trajetória e que uma pequena fração delas era refletida de volta, o que o levou a propor que o átomo possuía um pequeno núcleo maciço com carga positiva, em torno do qual orbitavam apenas alguns elétrons, como se o átomo fosse um sistema solar em miniatura. Entretanto, do ponto de vista do eletromagnetismo clássico, esse modelo seria instável (os elétrons ao redor do núcleo, por estarem acelerados, emitiriam ondas eletromagnéticas - como ocorre com uma antena transmissora - e perderiam energia até colidir com o núcleo), contrariando todas as evidências esperadas. 
Assim sendo, a história expressou, através de Bohr, a suposição de que as leis físicas que descrevem o mundo macroscópico não se aplicam ao mundo atômico. Incorporando o conceito de Planck ${ }^{11}$ (explicitado na virada do século XIX para o século $\mathrm{XX}$ relativo à energias discretas) e o de Einstein (explica o processo de absorção de radiação pela matéria), Bohr propôs que os elétrons descrevem órbitas bem definidas em torno do núcleo e que o estado fundamental do elétron corresponde à órbita de mais baixa energia, a partir do qual se encontraria "livre" da influência do núcleo, podendo, nesse caso, ter energias arbitrárias. As transcrições previstas por seu modelo, uma vez consistentes com os dados espectroscópios disponíveis na época, impulsionaram várias pesquisas que culminaram com a formulação da mecânica quântica (VALADARES, 2005). Entretanto, apenas na década de 1920, a teoria quântica se transformou na Mecânica Quântica, proporcionando uma compreensão mais profunda da dualidade onda-partícula, com De Broglie, Schrödinger, Heisenberg, Bohr e outros. A teoria quântica nos permitiu a compreensão de fenômenos importantes como a estrutura de átomos e moléculas (que forma a base de toda a química), o comportamento dos elétrons e das partículas de luz, a estrutura de sólidos e suas propriedades, a emissão e absorção de radiações. Donde, partículas quânticas dizer respeito ao universo das dimensões atômicas ou moleculares (DADIDOVICH, 2004).

Portanto, depois que os instrumentos foram transformados, teleogicamente pelos homens, de "máquina-ferramenta-automática que opera 0 objeto macroscopicamente" em "máquina-ferramenta-automática que incide no objeto atomicamente", por meio de alterações nos conjuntos de sistemas de partículas quânticas, a produção da existência dos homens adquire uma forma independente, inteiramente livre, dos limites da máquina-ferramenta-automática, de incursão clássica, de ação sobre a forma exterior do objeto. Com isso, o laboratório isolado que observamos até agora, reduzido ao simples elemento da produção automatizada (na grande indústria, no século XIX), passa a ser o complexo elemento da produção automatizada: o sistema de laboratório. Assim, o fazer atômico/molecular impulsionou, ao mesmo tempo, a constituição de novas forças produtivas e de novas áreas da ciência como, também, o desenvolvimento das existentes. As máquinas motrizes (motores) se adequaram, reduzindo seu tamanho, para impulsionar o novo sistema de 
máquina-ferramenta-automática já diminuído em suas proporções: somente assim, a natureza da força motriz, a energia elétrica, diminuiu, generalizadamente, o tamanho do motor e do mecanismo de transmissão. Desse modo, a revolução iniciada em fins do século XIX não produziu nem o desenvolvimento da eletricidade nem a invenção de máquinas movidas a eletricidade. Ao contrário, a eletricidade e a máquina elétrica alcançaram tal importância porque o laboratório e a crescente decomposição dos processos parciais da produção na grande indústria fizeram possível e necessário desenvolver, como processo objetivo, um mecanismo adequado a superar as barreiras existentes (colocadas pela grande indústria), e, então, a máquina elétrica, que havia sido engendrada pela grande indústria, encontrou um campo preparado para sua aplicação como motor.

Enquanto que o ponto de partida singular da grande indústria são os instrumentos de trabalho, o ponto de partida singular do sistema de laboratório são os objetos de trabalho. Assim, os elementos constituintes da matéria (as moléculas e os átomos), cuja importância para as concepções em nanotecnologia é maior são: Hidrogênio $(H)$, Carbono $(C)$, Nitrogênio $(N)$, Oxigênio $(O)$, Flúor $(F)$, Silício $(S i)$, Fósforo $(P)$, Enxofre $(S)$ e Cloro $(\mathrm{Cl})$. Outros elementos são utilizados com menos freqüência. Em sendo assim, por suposto, no laboratório também o instrumento de trabalho é muito importante, pois sua existência serve à decomposição-composição desses elementos, mas a revolução de todo o processo de produção, no século $X X$, que foi preparada, dentro dos limites da grande indústria do século XIX, pela decomposição e composição dos intrumentos - dos componentes do sistema de máquinas, a saber, força motriz, mecanismo de transmissão e máquina-ferramenta-automática -, não veio da força motriz, do mecanismo de transmissão ou mesmo do seu mecanismo executor, mas do objeto e das possibilidades dos homens em desenvolver as forças produtivas e delas se separar, tendo como resultado sua própria eliminação como força produtiva imediata, por decomporem e criarem da matéria. Logo, mesmo que o mecanismo executor e as outras partes da máquina existam para alterar composição atômica e/ou molecular do objeto, sendo componentes muito importantes do laboratório, não é esse o aspecto determinante do caráter fundamental do sistema de laboratório, apesar de sinalizar aquilo a partir do que nasce algo que pode ser o equivalente do germe (ou aquilo que 
vem a ser a possibilidade do germe, do novo). Assim, a revolução iniciada em fins do século XIX não produziu nem o laboratório nem a ciência como elemento complexo que produz o fazer atômico/molecular (o sistema de laboratório), mas, ao contrário, a máquina-ferramenta-automática que incide no objeto atomicamente/molecularmente alcançou tal importância precisamente porque a união (cooperação) e o vínculo (intercâmbio) - materiais - desenvolvidas pelos homens, através da objetivação do

processo de desenvolvimento/decomposição na grande indústria, fizeram possível e necessário desenvolver tal instrumento que já havia sido engendrado durante todo o século XIX e que encontrou, em fins do século XIX/princípios do século XX, um campo preparado para sua aplicação. ${ }^{12}$ Desse modo, a ciência se revela o fazer dos homens, produto da práxis humana, considerando sua capacidade em desvelar a natureza a partir das condições materiais e socialmente postas.

\subsection{O PROCESSO DE PRODUZIR DO SISTEMA DE LABORATÓRIO}

A interação entre as várias áreas da ciência se exprime, na produção realizada no sistema de laboratório, de duas maneiras: a) no sistema de máquinas automáticas, sintetizado num só aparelho e b) na interação de múltiplos sistemas de máquinas automáticas, materializada em vários aparelhos que atuam conjuntamente.

No primeiro modo de interação, cada aparelho é a síntese diminuta da combinação de máquinas de diferentes espécies e habilidades dos homens - ou, do "verdadeiro sistema de máquinas", conforme Marx (1996, p.432) -, que opera sobre o objeto. Abstraindo a interação dos aparelhos entre si, observando um aparelho isoladamente, a transformação que se opera sobre o objeto é desprovida de caráter subjetivo ${ }^{13}$. Pelo aparelho, a execução é objetiva em si mesma, por meio dos seus diversos componentes, e o problema de levar a cabo cada um dos diversos processos e de entrelaçá-los é resolvido com a aplicação de outros domínios da ciência (LATOUR, $1997)^{14}$. Parece que executa, nesse caso, todos os movimentos necessários para a transformação "sem ajuda humana", pois a intervenção humana (que requer habilidades específicas) ocorre em função da vigília e/ou término da vigília sobre o processo. Entretanto, o ser social, o humano, está expressado/materializado no aparelho. 
No segundo modo de interação, o conjunto dos vários aparelhos (cada qual constituindo um sistema de máquina diminuto), acrescidas as habilidades dos homens vivos para, teleologicamente, decomporem partículas quânticas, em si e para si, constituem o sistema de laboratório. Não são os aparelhos, isoladamente, que constituem o elemento fundante do sistema de laboratório, mas os vários aparelhos específicos conjuntamente com as habilidades dos homens. ${ }^{15} \mathrm{~A}$ cooperação entre os homens não ocorre sob a forma de combinação de um único sistema de máquinasferramenta-automáticas parciais complementares, tal qual na grande indústria (que patenteia o verdadeiro sistema de máquinas, segundo Marx, (1996)) em que as máquinas controlavam os homens, predominantemente ao controle destes sobre as mesmas. ${ }^{16}$ A cooperação ocorre sob a forma da combinação de vários sistemas de máquinas-ferramenta-automáticas, expressados nos vários aparelhos. Desse modo, os aparelhos específicos e as habilidades (ambos provenientes de outros domínios) se transformam em órgãos adequados de uma função especial: cada um dos vários sistemas de laboratórios se distingue, pela configuração particular dos vários aparelhos existentes, para responder a uma necessidade bem definida. O sistema de laboratório reproduz dois elementos que na indústria moderna emergiram como pressupostos, porém, coloca-os como condições postas.

O primeiro é a substituição do homem por forças naturais, e, conseqüentemente, da rotina empírica pela aplicação consciente da ciência no processo produtivo. O segundo é que 0 processo mecanizado só funciona "por meio de trabalho diretamente coletivizado ou comum" (AUED, 2005a, p.20).

A própria grande indústria, de modo geral, fornece ao sistema de laboratório a base original da divisão e organização do trabalho. ${ }^{17}$ Entretanto, se verifica imediatamente uma diferença essencial.

$\mathrm{Na}$ produção automatizada da grande indústria desaparece o princípio subjetivo da divisão do trabalho, porque o processo por inteiro é examinado objetivamente, em si mesmo, em suas fases componentes, e o problema de levar a cabo cada um dos processos parciais e de entrelaçá-los é resolvido com a aplicação técnica da mecânica, química, etc., (MARX, 1996, p.433-434). Donde o caráter cooperativo do processo de trabalho ser, sob as condições burguesas, uma 
necessidade técnica imposta em função da natureza do próprio instrumental de trabalho e não da idéia dos homens (Op.cit., 20-21). Parece, na grande indústria, que não há general intellect e sim "idéias de homens", mas, de fato, ele está expressado como universalidade objetivada, porque seu pressuposto é a decomposição da subjetividade do trabalhador coletivo manufatureiro, cujo resultado é a máquina. Em função de o general intellect estar objetivado, exteriorizado, como instrumento de trabalho, a ciência aparece como externa à produção material, como "coisa da cabeça dos homens", e a força universal pensante aparece como domínio objetivo do capital.

Já no sistema de laboratório, o processo de produção depende de uma certa materialidade, distinta da materialidade da grande indústria, não somente objetivada como meios de produção, mas como objeto com o qual se trabalha. Sendo assim, o caráter geral material do processo se expressa no e pelo general intellect, como força universal pensante, porque sendo os processos parciais (realizados pelos aparelhos) que o constituem examinados objetivamente em si mesmo, a universalidade como objetivação se expressa não somente nos aparelhos, mas também - e fundamentalmente -, materialmente, no homem pensante, teleologicamente posto. Nesse sentido, o general intellect, posto pelo sistema de laboratório, é pura ação humana intelectual, consciente e objetivamente posta, porque tem por pressuposto a decomposição do trabalhador coletivo materializado na máquina, cujo resultado são os aparelhos de laboratório que decompõe a matéria. Nisso reside o caráter revolucionário/salto ontológico do processo de produzir.

No entanto, esse processo aparece como construído pelos aparelhos, em que reside a construção de uma "realidade artificial", da qual os homens falam como se fosse uma "entidade objetiva", mas, na verdade, é a aparência do processo real de produção (LATOUR, 1997).

Os homens "vão fazendo a transformação geral" com cada aparelho e a habilidade requerida para manipulá-lo, mediante essas operações parciais, segundo as funções específicas a que se destinam dentro do laboratório (por exemplo, um sintetizador de peptídeos): em si, essa operação parcial é objetiva e expressa o processo social de produção. Da mesma forma, com o conjunto dos aparelhos e das habilidades requeridas à necessidade final, desse sistema de laboratório, os homens, 
como seres sociais pensantes, operam uma transformação final que é eminentemente coletiva, em que reina o princípio objetivo e que expressa o processo social de produção.

Observando amplamente, a necessidade final é produzida por aparelhos e habilidades que dependem não somente do próprio sistema de laboratório (no sentido de estarem a ele vinculados), mas, materialmente, de outros domínios da ciência - no que reside o caráter social de sua condição. Somente a partir dessa condição geral do processo de produção e das várias execuções parciais os homens "efetivam a transformação final" ou satisfazem sua necessidade final (também dos outros).

Portanto, entendemos esse processo de duas maneiras.

Isoladamente, é, ao mesmo tempo, objetivo e um coletivo de homens que cooperam objetivamente, no sentido de que, uma vez produzida a inscrição, que contém indicadores diretos das substâncias que constituem o objeto de estudo - o dado objetivo -, os homens se unem para pensar as idéias, os conceitos, ou as teorias particulares (LATOUR, 1997).

Socialmente, é materialmente cooperativo, pois depende da condição geral (das condições objetivas imediatas e de homens que manipulam aparelhos, e das condições coletivas de homens que se unem para operar objetivamente por meio do pensamento) dada por outras áreas da ciência.

Isso porque pela alienação, o homem, ao reproduzir a substituição dele mesmo por forças naturais e por um processo que só funciona por meio do trabalho comum, engendra uma base produtiva de sua existência cujo caráter cooperativo do processo de trabalho, em função da natureza do próprio instrumental, é uma necessidade técnica das idéias dos homens pensantes, teleologicamente postos. Essa necessidade é a própria utilização do trabalho passado como condição posta da produção da vida em dimensão superior às legadas pelas gerações presentes (AUED, 2005a).

Ocorre que, no sistema de laboratório, o ponto de partida é o objeto com o qual se trabalha e não os instrumentos de trabalho tal como na grande indústria. Somente no sistema de laboratório, a decomposição atômica/molecular do objeto, esse conhecimento da matéria como condição social da produção, se coloca como 
necessidade socialmente imposta. A grande indústria, ao se assentar sobre 0 laboratório, engendrou o germe do que vem a ser o sistema de laboratório, sua superação. Na infância do sistema de laboratório (o laboratório), as transformações estão ainda vinculadas não somente à necessidade de eficientizar o processo de trabalho (essencialmente nos ramos em que o processo de produção ainda não é objetivo, a ponto do grau de decomposição permitir expulsar homens da produção), mas fundamentalmente, à decomposição das próprias máquinas automáticas (instrumentos), em cada um dos processos parciais do autômato. O aperfeiçoamento, por meio do laboratório, dos instrumentos com os quais se produz - e isso, o mais necessário nesse momento histórico em que se desenvolve a grande indústria considera sempre a forma exterior do objeto, não porque não importe ser diferente disso, mas porque não há como ser diferente.

Aparentemente, no sistema de laboratório, os homens "reaparecem" como essenciais ao processo (pois haviam sido relegados, na grande indústria, ao nível de apêndice do sistema de maquinaria), tal como o tinham sido na manufatura. Entretanto, agora, o processo é levado a cabo pelo general intellect - entendido por nós como "[...] a ciência, o produto do desenvolvimento histórico geral em sua quinta-essência abstrata [...]" (MARX, 1987, p.387) -, como determinação social da produção material que se expressa como conhecimento da constituição da matéria e homem pensante. ${ }^{18} \mathrm{Na}$ grande indústria (em seus inícios), o general intellect também é posto pela determinação social da produção material, via laboratório, mas essa determinação é operação sobre o objeto, transformando-o exteriormente, cuja eficiência prescinde da necessidade de conhecimento da constituição da matéria (hoje já não mais). Por que a eficiência da transformação, na grande indústria, pode prescindir do conhecimento da constituição da matéria? Porque esse conhecimento não é determinado por esse espaço, mas pelo sistema de laboratório. Agora é a grande indústria que depende inteiramente do sistema de laboratório e não o contrário. Donde, a diferenciação entre o aperfeiçoamento da teoria através da experiência acumulada na grande indústria (que se expressa idealmente nos princípios clássicos) e no sistema de laboratório (que se expressa idealmente nos princípios quânticos relativos à química, física, etc.) (O laboratório - na grande indústria - tem sua expressão ideal somente por princípios 
clássicos, mas o sistema de laboratório - o que há de mais avançado - tem sua expressão não somente nos princípios clássicos, mas fundamentalmente nos quânticos. Logo, não se trata, hoje, da grande indústria de outrora. A grande indústria se transmuta, ao ser determinada pelo sistema de laboratório, passando a integrar uma nova totalidade: antes, foi engendrada pela manufatura, que alterava a forma exterior, e agora é a parte operacional do sistema de laboratório).

Para além de encurtar a parte do dia de trabalho da qual o trabalhador precisa para si mesmo, o trabalhador social engendra o pressuposto material de superação da própria alienação ao criar a máquina-ferramenta-automática que decompõe partículas quânticas (o fundamento do sistema de laboratório). Isso porque o material orgânico do ser social, como corpo do homem, é o mesmo da natureza. Em outras palavras, o sistema de laboratório evidencia que o homem altera/produz sua natureza, ao produzir a natureza externa. Entretanto, a alienação ainda não se resolve por completo, pois os homens ainda não produzem outros homens, em si e para si, mas enquanto exterioridade que é capital. Cada aparelho, síntese diminuta do sistema de máquinas automáticas da grande indústria, opera sobre determinado objeto fornecendo matéria-prima a outro aparelho. Tais aparelhos não necessariamente funcionam de forma simultânea, de modo que o produto se encontre simultaneamente em todas as fases de transição (o mesmo não se pode dizer da produção laboratorial industrial, que fornece elementos ao sistema de laboratório). Por isso, a cooperação entre os homens, no sistema de laboratório, não estabelece proporções quantitativas entre setores especializados, com referência ao número ou velocidade dos aparelhos, mas qualitativas referentes à funções dentro da equipe que podem ou não estar vinculadas a algum tipo de aparelho: são especificações técnicas e avaliativas de crédito dos indivíduos, socialmente requeridas (LATOUR, 1997) ${ }^{19}$. O general intellect se objetiva no homem. A continuidade dos processos parciais, os quais são efetivados objetivamente por aparelhos, é um princípio fixado pela universalidade do processo social de produção, pelo general intellect. Note-se que a força engendrada socialmente pelos homens em cooperação adveio de um processo historicamente determinado e que expressa a criação universal entre todos os homens na produção material de sua existência. Nesse sentido, na medida em que os aparelhos se universalizam em todos 
os campos, a divisão do trabalho (nas condições burguesas) tende a desaparecer. Observe-se que, na grande indústria, a universalidade objetivada é a interligação, pois o universal como máquina está secionado. Sendo assim, observamos divisão das máquinas, mas não dos homens, pois estes acompanham as máquinas, as quais modificam formas e criam objetos, só então ocorrendo divisão técnica. Já no sistema de laboratório, o universal é a máquina singular (aparelho) e todos os sistemas de laboratórios (de modo a não estar secionado). Logo, pelo pensamento, os homens são igualados; o que os diferencia é o grau de informação do conhecimento. Entretanto, por ser essa condição do trabalho pura abstração, tende a negar a divisão do trabalho como subsumida pela lógica do capital, na medida em que tem os pés bem assentes na terra.

O sistema de laboratório se baseia na combinação de aparelhos de diferentes espécies constituindo, ao mesmo tempo, um corpo orgânico e inorgânico. Conforme Fausto (2002), talvez porque discuta pela ótica da importância do trabalho vivo, se diria que reaparece a comunidade de homens perdida na grande indústria - na grande indústria, a comunidade que se objetivou é a de máquinas. Mais além dessa perspectiva, para nós, está o trabalho social em sua forma mais avançada. Inferimos, de qualquer modo, que, por isso mesmo, tal comunidade "perdida" necessita se assentar sobre a ciência (o laboratório) para se desenvolver. Os homens, antes apêndice na linha de produção na grande indústria, não continuam sendo apêndice no sistema de laboratório devido à transformação que agora se realiza - desvencilhada dos limites da grande indústria - e por causa disso pelo fato de passarem a se apropriar do objeto pela compreensão da natureza, em sua constituição estrutural atômica/molecular. Na grande indústria, eles também se apropriavam objetivamente da natureza ${ }^{20}$, mas essa apropriação não tinha como condição socialmente imposta, a compreensão da natureza, o conhecimento e domínio da composição atômica/molecular do objeto através do ser social. Na grande indústria, a decomposição da matéria não era, essencialmente, imperativa e, por isso, a transformação se dava por um processo de conhecimento da natureza:

[à] medida que os homens, em processo contínuo e constante, apropriam-se da natureza sensível ao dominar suas leis imanentes, desenvolvem-se meios de produção que permitem 
ao homem dominar, controlar, moldar e imprimir-lhe formas que lhes são necessárias à satisfação de suas necessidades. (AUED, 2005b, p.21)

O fato de cada um dos aparelhos do sistema de laboratório possuir um motor próprio exprime a funcionalidade de gerar eletricidade a partir de vários tipos de reações e a necessidade de os homens tornarem possível a produção de novas fontes de energia (eólica, solar, etc.) em larga escala. Quando os aparelhos, ao operarem sobre o objeto, executam "sem ajuda humana" todos os movimentos necessários para a transformação da matéria (o homem somente a vigia), necessitando de intervenção humana apenas para levar o objeto de um aparelho a outro, temos um sistema de laboratório. De fato, se trata da cooperação de homens se apropriando, se objetivando, ser social.

A produção automatizada da grande indústria, que traz em suas entranhas a constituição do laboratório, encontra sua forma mais desenvolvida no aparelho do sistema de laboratório, que recebe seus movimentos de uma força motriz externa ou interna (no caso de um gerador) - note-se que o aparelho já contém um motor e os meios de transmissão. Por isso, surge no lugar do "monstro mecânico que enche edifícios inteiros e cuja força demoníaca se disfarça nos movimentos ritmados quase solenes de seus membros gigantescos e irrompe no turbilhão febril de seus inumeráveis órgãos de trabalho" (MARX, 1996, p.435), uma máquina isolada de proporções bem menores, que conjuntamente com outras ocupa um espaço bem menor. O aperfeiçoamento dos aparelhos está ligado ao que se passa em outros domínios envolvendo principalmente a física, química, biologia, engenharia elétrica e ciência dos materiais, enfim, áreas relacionadas à compreensão da estrutura atômica/molecular da matéria e ao conhecimento do objeto (em sua forma exterior). Assim, a grande indústria, cujo ponto de partida é o "autômato orgânico", na medida em que passa a ser decomposta pelo laboratório - mas esse é, inicialmente, um apêndice do desenvolvimento/decomposição das partes constituintes da maquinaria (força motriz, meio de transmissão e máquina-ferramenta-automática) -, supera através do sistema de laboratório a limitação de transformar os objetos prescindindo de compreender a estrutura atômica da matéria. A decomposição - através do laboratório como expressão ideal da grande indústria, pois se assenta sobre determinado conhecimento, o clássico 
newtoniano - da máquina-ferramenta-automática que incide sobre o objeto constrói fenômenos que não são passíveis de ser explicados pelo próprio conhecimento que os geraram. E o laboratório, antes apêndice, se autonomiza da grande indústria e a "supera incorporando-a" (numa palavra, passa à relação de sistema de laboratório), ao se expressar como materialidade que decompõe a estrutura da matéria através da composição de diversos aparelhos (sínteses diminutas do "autômato orgânico") pertencentes a diversos domínios. A partir desse momento, outra abordagem material (sistema de laboratório) e teórica (conhecimento quântico) dos fenômenos físicos passa a constituir o elemento fundante da reprodução da existência dos homens. Eis no que reside o ponto de partida do sistema de laboratório: os próprios objetos, a constituição da matéria.

\subsection{SUPERAÇÃO DO SISTEMA DE LABORATÓRIO?}

Se afirmamos que foi justamente a necessidade dos homens de produzir sua existência que revolucionou a grande indústria, como explicar as "mudanças tecnológicas" propagadas a partir da década de 1970? O que distinguiria esse segundo momento (se é que pode vir a ser considerado como momento superior)?

Em princípios do século $\mathrm{XX}$, mesmo sendo revolucionária, a máquinaferramenta-automática, que significava desvelar o objeto atômica/molecularmente, não permitia a manipulação individual de partículas quânticas. Precisamente, em 1981, os homens produzem essa "invenção" por Gerd Binnig e Heinrich Rohrer: o Microscópio Eletrônico de Tunelamento por varredura (STM na sigla inglesa) ${ }^{21}$. Com esse equipamento, foram obtidas as primeiras imagens individuais de átomos e moléculas, superando todas as técnicas de observação e de medida até então usadas e possibilitando uma nova visão da ciência sobre a matéria e o desenvolvimento das técnicas de nanotecnologia - área da tecnologia que permite manipular os constituintes da matéria e medir seu tamanho. Já existiam microscópios eletrônicos de alta resolução, mas esse, desenvolvido em 1981, e todos os que se seguiram são dotados 
de uma ponta de prova ou sonda "[...] a única ferramenta capaz de obter imagens tridimensionais de altíssima resolução".

Além disso, [esses microscópios] podem medir propriedades físicas da superfície da amostra - entre elas condutividades, distribuição de cargas elétricas, atritos microscópicos, elasticidade, dureza, rigidez, microfluorescência e índice de refração. Podem também estudar propriedades relacionadas ao eletromagnetismo da matéria, como por exemplo, as paredes de domínios elétricos e magnéticos. (ZANETTE\&CARIDE, 2000, p.34)

Em pouco mais de 20 anos, após a criação do microscópio de efeito túnel, os homens desenvolveram uma grande família de instrumentos conhecida por SPM (sigla, em inglês, para microscópios de varredura por sonda), mais eficientes em termos técnicos e mais baratos $^{22}$, como, por exemplo, o AFM (sigla, em inglês, para microscópio de força atômica) ${ }^{23}$, o SNOM (sigla, em inglês, para microscópio óptico de varredura de campo próximo), além de uma grande diversidade de outros aparelhos cuja finalidade é determinada pelo estudo que se quer fazer. ${ }^{24}$

Em seus princípios, a física quântica, sendo a expressão ideal da máquinaferramenta-automática de precisão quântica (capaz de captar os elétrons, prótons, nêutrons, fótons, etc...), afirmava, distintamente da física clássica, que não era possível medir entidades quânticas (elétron, nêutron, fótons, etc.) por sua posição e seu momento (pelo produto de sua massa por sua velocidade) e muito menos o estado de uma única entidade quântica, pois as leis da física obrigariam a ter um conjunto muito grande delas (idealmente infinito). ${ }^{25}$ Se poderia medir apenas probabilidades de a medida fornecer os vários valores possíveis para as grandezas relevantes ${ }^{26}$; assim, ainda que fosse possível medir uma única unidade quântica, o que permitiria medir seu estado, "qualquer medida feita sobre um sistema quântico necessariamente perturba seu estado e, portanto, o altera" (DADIDOVICH, 2004, p.24).

A explicação dos fenômenos quânticos até então observados corroborava se tratar sempre de conjuntos de sistemas - envolvendo a idéia de probabilidade - e jamais de sistemas individuais. No entanto, a pioneira idéia de R. Feynman, manifestada numa palestra, em 1959, sobre a possibilidade de manipulação individual de átomos considerada absurda à época - é expressão de que já havia condições materiais para tanto. Nos anos 1940, por exemplo, já tinham sido desenvolvidos (certamente por conta 
da segunda guerra mundial) métodos de visualização especiais, baseados em microscópios que não utilizavam luz visível, aumentando o poder de resolução dos microscópios eletrônicos. ${ }^{27}$ Dessa maneira, o problema de manipular individualmente os átomos foi, somente, levantado porque as condições materiais para resolvê-lo já existiam ou estavam em vias de se desenvolver. Inversamente, a palestra de Feynman foi "resgatada na história" porque a questão de manipular individualmente os átomos se mostrou em vias de se resolver pela materialidade, concretamente cerca de vinte anos mais tarde. A "invenção" de Gerd Binnig e Heinrich Rohrer (em 1981) e a de todos os microscópios seguintes puderam se concretizar porque se tinha à mão uma qualidade de trabalhadores e de aparelhos, trabalho vivo e trabalho objetivado, desenvolvidos do sistema de laboratório até então (esses trabalhadores são pesquisadores dependentes, de domínios diversos da ciência em que reina a divisão - burguesa - intelectual do trabalho). Com a constituição dessas condições e a necessidade crescente de dominar o sistema de átomo em conjunto, cada vez mais se desenvolveram, diferenciando-se em ramos dependentes diversos: a) a produção de microscópios e aparelhos relacionados à decomposição da matéria (química, biologia, etc.) e b) o processo social de produção, por meio do general intellect - ambos em direção ao sistema de laboratório que decompõe partículas quânticas individualmente. ${ }^{28}$

Como vimos, o laboratório da grande indústria constituiu base técnica imediata do sistema de laboratório. O primeiro produzia os fenômenos e as máquinas com que o segundo eliminava, melhor dizendo, superava incorporando, a forma de produção da existência (como elemento fundante), que transforma instrumentos para operar a forma exterior do objeto. A produção da existência no laboratório se erguia sobre uma base que the era inadequada. Atingindo certo estágio de desenvolvimento, o próprio laboratório removeu a base que encontrou pronta e a aperfeiçoou, em sua forma antiga, para estabelecer nova base adequada a seu modo de produção. ( $O$ autômato orgânico era de tamanho monstruoso enquanto o laboratório era seu apêndice, e os aparelhos do laboratório, constituintes do sistema de laboratório, não puderam se desenvolver livremente antes de se decomporem os elementos do sistema de máquinas, precisamente a máquina-ferramenta-automática de incursão atômica - o espectroscópio disponível na época). Do mesmo modo, o sistema de laboratório ficou 
amarrado em todo o seu desenvolvimento, enquanto seu instrumento de produção característico, a própria máquina-ferramenta-automática de incursão atômica, devia sua existência à própria máquina (instrumento característico da grande indústria), que dependia das velhas formas de força motriz, de meios de transmissão e da máquinaferramenta-automática de incursão clássica. Colocando-se de lado o barateamento/economia que esses aparelhos, desenvolvidos por tal processo, significam, a constituição do sistema de laboratório e sua penetração em novos ramos da grande indústria ficaram na dependência exclusiva de uma classe de trabalhadores, dotados do general intellect, que aumentou lentamente em virtude da natureza intelectual de suas ocupações e do incipiente grau de desenvolvimento geral, pois era necessário investigar/decompor a constituição da matéria. As duas Guerras Mundiais contribuíram para acelerar esse desenvolvimento. Além disso, em certo estágio, o sistema de laboratório entrou, tecnicamente, em conflito com a base que possuía, o laboratório: na pesquisa sobre os elementos mais simples constitutivos à matéria não bastava continuar examinando a superfície das coisas, simplesmente medindo o peso, a cor ou as propriedades químicas superficiais; foi preciso penetrar profundamente no coração das substâncias.

Resulta, hoje, que a nanotecnologia diminui crescentemente as dimensões dos seus próprios aparelhos (seu motor, os mecanismos de transmissão e a máquinaferramenta-automática); há maior complicação e diversidade, há ajustamento mais minucioso dos elementos componentes à medida que a máquina-ferramentaautomática, o microscópio eletrônico de tunelamento por varredura, se desprendeu do modelo em que se baseava, o microscópio eletrônico; há aperfeiçoamento do sistema automático e aplicação cada vez mais inevitável de novos materiais: todas essas condições surgem historicamente e sua solução encontra limitações que só o trabalhador coletivo pode transpor, superando-as qualitativamente. A grande indústria e o laboratório, a ela agregado, não podiam produzir objetos como nanotubos de carbonos $^{29}$ e dendrímeros ${ }^{30}$.

Com o sistema de laboratório, a revolução no modo de produzir acaba se propagando aos laboratórios e à produção industrial. É o que se verifica principalmente nas redes de laboratórios e nos laboratórios que, mesmo isolados pela divisão social do 
trabalho - sob as condições burguesas de produzir - constituem fases de um processo global. ${ }^{31}$ Assim, sistemas de laboratórios de nanobiotecnologia tornam necessária a reordenação da produção em setores relacionados a biossensores, bioreceptores, farmácia, ambiental e alimentos; sistemas de laboratórios de tecnologia e nanofabricação de Silício, a reordenação de métodos de microeletrônica visando a nanoeletrônica, circuitos à base de nanotubos, caracterização de nanocircuitos; laboratórios de espectroscopia, a reordenação da produção na agroindústria; sistemas de laboratórios de nanodispositivos fotônicos, a reordenação de setores relacionados à fotônica, optoeletrônica e sensores óticos, etc. A revolução no modo de produção, com o sistema de laboratório, pois se manipula individualmente os átomos, torna, sobretudo, necessária uma revolução nas condições gerais do processo social de produção, isto é, nas formas de forças motrizes, dos meios de transmissão e da constituição estrutural dos materiais, em outras palavras, na constituição do modo como os homens produzem sua existência. Assim como a forma da força motriz (vapor) e dos meios de transmissão (válvulas) da velha sociedade, (a partir da qual os homens, produzindo sua existência, produziam máquinas automáticas - como elemento fundante - que operavam a forma exterior do objeto), não pôde, de modo nenhum, satisfazer às necessidades do sistema de laboratório em decompor conjuntos de sistemas de partículas quânticas, (pois exigiam uma nova configuração do trabalho social - intelectual -, um novo grau de intercâmbio e interconexão entre as diferentes áreas da ciência, com sua concentração de aparelhos - num espaço físico livre do domínio da grande indústria - e de uns poucos trabalhadores - providos do general intellect, isto é, da ciência, o produto do desenvolvimento histórico geral em sua quinta-essência abstrata -), sendo, por isso, inteiramente transformada; do mesmo modo, as atuais formas de força motriz (energia elétrica) e de meio de transmissão (transistores), legados do período anterior, podem e devem, atualmente, ser superadas ${ }^{32}$, em suas limitações, pelo sistema de laboratório, que decompõe individualmente o sistema do átomo, com sua capacidade de transformar a produção em grande escala a partir do objeto (o átomo, no termo individual) -, para que a grande indústria continue a expulsar trabalhadores do processo de produção e a deslocar massas de capital de um ramo de produção para outros (de maior composição orgânica), de uns países para outros, com as novas conexões que 
cria no mercado mundial - processo esse resultado do desenvolvimento dos elementos já constituídos durante a primeira metade do século $\mathrm{XX}$.

O sistema de laboratório, atualmente, ao se apoderar da decomposição individual do sistema de átomo, trata, assim, de criar sua base técnica adequada, se autonomizando do general intellect que se funda na forma objetiva do "trabalho vivo" (na "subjetividade" dos trabalhadores - os "cientistas") e que decompõe o sistema de átomo individualmente. Note-se, novamente, que os homens se vêem cada vez mais unidos e libertos na medida em que as forças produtivas são criadas (aufhebung) pelos homens, pois delas se separam, cujo resultado é a eliminação (emancipação) do homem como força produtiva direta relacionada ao tempo de trabalho. Vejamos 0 tipo de desenvolvimento que está posto, atualmente, pela decomposição individual do sistema de átomo, segundo o professor Frederic Levy, membro da Academia Interdisciplinar de Ciências de Paris (AISP).

Um dos pontos fundamentais do domínio da nanotecnologia é, portanto, a criação de uma máquina, de tamanho molecular, capaz de duplicar-se a si mesma. A fim de poder criar outras coisas, que não cópias de si mesma, é, logicamente, indispensável que ela possa igualmente fabricar outras estruturas! Os programas de pesquisa têm, portanto, por objetivo, fabricar uma primeira versão dessa nanomáquina, chamada montador [nota do autor: 'Empregamos o termo "montador", do português, para o conceito "assembleur", do francês, visto não se contar, ainda, com tradução para o mesmo']. Tal montador seria uma máquina contendo alguns milhões de átomos, com pelo menos um braço manipulador, que permita colocar os átomos - um por um -, no lugar desejado. Uma vez fabricada essa primeira versão, embora que de forma bastante rudimentar, mesmo que em poucos exemplares, será possível, então, fabricar outras mais evoluídas, e criar as primeiras nanomáquinas...Estão atualmente em curso diferentes vias de acesso a esse primeiro montador, entre elas destacamos: - a construção direta, com a ajuda dos microscópios, anteriormente mencionados; - a automontagem, por engenharia genética. No entanto, é importante frisar que nenhuma dessas vias está perto de, num futuro bem próximo, atingir os resultados almejados! Deve também ser dito que nenhum montador foi ainda concebido em todos os seus detalhes. Vários elementos de nanomáquinas foram propostos: alguns deles para a parte "ativa" de uma ferramenta que manipula os átomos, servindo à fabricação; outros, para o deslocamento do braço manipulador, etc. Restam, ainda, numerosos problemas de engenharia a serem resolvidos! O modo de comando de tal montador não é senão proposto muito esquematicamente. (As futuras gerações de montadores poderão ter seu próprio "nanocomputador" permitindo seu comando, contudo, os montadores das primeiras gerações deverão, de um modo ou outro, ser comandados por controle remoto). Os mecanismos de "fornecimento" de 
átomos e moléculas que servirão de material para construção do montador, igualmente ainda necessitam de estudos...Por outro lado, os microscópios atuais podem manipular alguns átomos, mas dificilmente tem-se em vista utilizá-los para fabricar diretamente uma máquina que contenha vários milhões de átomos...A automontagem por engenharia genética permite utilizar instrumentos modernos de manipulação de pedaços de DNA. Assim, diversos laboratórios tiveram sucesso na fabricação de estruturas, criando e ligando vários segmentos de DNA entre si. Talvez seja possível criar um primeiro montador constituído de pedaços de DNA. Todavia, a leitura de trabalhos em curso revela que, o modo como isto seria feito, está ainda pouco claro...Uma via de investigação ligada a essa área é a da pesquisa com os fulerenos. Os Senhores talvez já conheçam essas moléculas de carbono, recentemente descobertas, e que deram o Prêmio Nobel a Richard Smalley, um dos principais promotores da Nanotecnologia Molecular. São numerosas suas aplicações, entre elas o melhoramento de ferramentas de manipulação de átomos. No momento, pesquisadores tentam atualizar métodos de produção industrial dessas estruturas. Finalmente, uma direção de pesquisa paralela é aquela que trata da concepção computacional de estruturas moleculares, de nanomáquinas e de nanocomputadores. Tais trabalhos têm vários objetivos, entre eles: tentar assegurar o funcionamento dessas nanomáquinas e debruçar-se, desde já, sobre os problemas de engenharia a serem resolvidos quando dos primeiros montadores disponíveis. Esses poucos e descoordenados exemplos de pesquisas em curso são uma pequena amostra da atividade intensa e perturbadora existente atualmente nesta área. Numerosos documentos encontram-se disponíveis na Internet [...]. Foi, por exemplo, formada, na Internet, uma equipe de pesquisa internacional, cujo trabalho relaciona-se com todos os aspectos do desenvolvimento de um nanocomputador (concepção de materiais e hardware, técnicas de comunicação, confiabilidade, aplicações, etc.). (LEVY, 2000, p.11-14)

A condição essencial de produção para a fabricação da primeira versão de uma nanomáquina capaz de duplicar-se a si mesma é a construção direta, por meio dos microscópios anteriormente aludidos, e a automontagem por engenharia genética. Esses dois elementos já estão postos, mas, ao mesmo tempo, é necessário produzir os vários componentes dessa nanomáquina, resolver muitos outros problemas de engenharia e avançar nas pesquisas relacionadas à atualização dos métodos de produção industrial dos fulerenos (moléculas de carbono de numerosas aplicações, entre elas o melhoramento de ferramentas de manipulação de átomos). Os financiamentos para pesquisa aumentam exponencialmente e os programas descrevem, de modo cada vez mais direto, as técnicas e os objetivos da 
nanotecnologia. ${ }^{33}$ A "migração de cérebros", de homens que se reproduzem com salários, se assenta sobre uma nova base material em constituição.

Temos afirmado que os aparelhos do sistema laboratório constituem a síntese diminuta do "sistema de máquinas" da grande indústria, com a distinção de que esses aparelhos se destinam a compreender a estrutura da matéria. O sistema de laboratório primeiro decompôs os sistemas de partículas quânticas em seus conjuntos e agora decompõe o sistema do átomo em sua individualidade efetivando a possibilidade da construção de nanomáquinas auto-reprodutoras. Atentando para a composição de uma nanomáquina propriamente dita, vemos que nela reaparece o "autômato orgânico", mas em tamanho nanométrico, evidentemente.

No sistema de laboratório, a organização do processo de trabalho social é puramente objetiva. É a combinação da materialidade com o general intellect, expressão ideal dessa materialidade para ela mesma (se se quiser, é a combinação da objetivação do general intellect com o general intellect que se põe idealmente), pois é o produto do desenvolvimento histórico geral em sua quinta-essência abstrata. Por isso mesmo, o general intellect nada tem de subjetivo, com sentido de "imaterial". Entretanto, aparece e não aparece como subjetivo para o trabalhador individual, visto que esse se faz e não se faz alienado do caráter social do processo de produção. $O$ caráter cooperativo do processo de decomposição da matéria é uma necessidade técnica imposta pela natureza do próprio objeto de trabalho que se expressa pela objetivação no mais alto grau do general intellect - como sabemos, esse último já tinha sido, historicamente, objetivado nas máquinas da grande indústria. O caráter cooperativo do laboratório vinculado à grande indústria, na medida em que estava determinado pela máquina-ferramenta-automática de incidência sobre a forma exterior dos objetos, pois se limitava a aperfeiçoar os instrumento de trabalho, nunca poderia efetivar materialmente (objetivar) o general intellect como ideação (e não idealização). Só o caráter cooperativo do sistema de laboratório poderia fazê-lo objetivamente, pois tem no sistema de aparelhos, que decompõe a matéria, o organismo de produção inteiramente objetivo que o trabalhador encontra pronto e acabado como condição material da produção. 
Agora os homens se propõem a decompor o próprio sistema de laboratório. O objeto de trabalho, a matéria em si, ao se converter em nanomáquinas autoreprodutoras (conscientes, autônomas) e produtoras de nova materialidade, exige a supressão ou superação incorporando (e não substituição, pois não estão em condições de igualdade) das forças naturais e do general intellect para que os homens possam se apropriar do sistema atômico não em seu conjunto, mas em termos individuais, isto é, da existência dos próprios homens, individualmente em si. Isso acontece somente através do ato teleológico do ser social, isto é, da união dos homens (mesmo que para a produção do capital) que se transforma (aufhebung) ser para os homens, o qual efetiva a emancipação humana. Toda a, assim denominada, história mundial nada mais é do que o engendramento do homem mediante trabalho humano, vir-a-ser da natureza humana, é o nascimento do homem por meio de si mesmo, do seu processo de geração - é, por isso, a natureza efetiva do homem, mesmo que venha a ser por intermédio do sistema de laboratório, isto é, ainda que em figura estranhada -, a fim de que o "homem" se torne objeto da consciência sensível, e a carência do "homem enquanto homem" se torne necessidade (Marx, 2004); quando a força produtiva do trabalho social e sua forma particular se apresentarem na qualidade de força produtiva e forma não somente dos homens, do trabalho materializado, das condições materiais (objetivas) do trabalho, mas fundamentalmente para os homens. A união entre os homens

[...] se opõe aos próprios trabalhadores individuais como algo estranho e coisificado, como simples forma de existência dos meios de trabalho deles independentes e que os dominam, e do mesmo modo esses meios os enfrentam na forma visível, simples, de material, instrumento etc. nas funções de capital e, portanto, de capitalista. (MARX, 1987, p.386)

Entretanto, é por essa via, a objetivação da essência humana (tanto do ponto de vista teórico, quanto prático), que se exprime sistema de laboratório, que os homens fazem ser humanos, materiais, sociais e espirituais - numa palavra, o homem que é social -, os sentidos (não só os cinco sentidos, mas os sentidos espirituais, os sentidos práticos da vontade, do amor, etc.) do homem e o sentido humano, correspondente à riqueza inteira do ser humano e natural. O sistema de laboratório é, a natureza 
humanizada, a existência do seu objeto por onde vem-a-ser a humanidade dos sentidos e, ao mesmo tempo, o fazer homens, em si, separado do para si.

O sistema de laboratório é o vir-a-ser do homem social (da rica individualidade ao ser), historicamente, a síntese da supressão concreta do homem como força produtiva, como trabalho e capitalização (propriedade privada), pois nele estão postas a) a manufatura, a grande indústria e a quinta-essência abstrata do produto do desenvolvimento histórico geral como exteriorização do homem, b) a apropriação do sistema atômico/molecular, dos sistemas quânticos, individualmente e c) para além, a possibilidade de os próprios homens, individualmente postos, se relacionarem com $\mathrm{o}$ produto do seu trabalho exteriorizado, desmistificado e humanizado.

\section{PosSIBILIDADE DE INVESTIGAÇÃO NA EdUCAÇÃO NO SÉCULO XXI}

Sabemos que algo fundamental se modificou nos últimos 40 anos no modo como a humanidade produz o capitalismo e a si mesma. Na década de 1970, muito se falava em crise; na de 1980, os termos de moda foram reestruturação e reorganização; na de 1990, deixou-se de ter certeza de que a crise já estaria solucionada e começou a se difundir a visão de uma nova situação histórica do capitalismo, chamada por alguns de pós-moderna; na de 2000, fala-se de névoa, incerteza, transição, admitindo-se a possibilidade real de uma transformação radical (senão de colapso das relações capitalistas) e de abertura para relações de um tipo novo.

Nossa tese é a de que o modo de produção capitalista está atravessando um momento decisivo e que as transformações em curso não têm precedentes. À luz do princípio de que a história não se repete, seu primeiro pressuposto é a consideração da afirmação, negação e superação do modo de produção capitalista à luz do movimento de sua base material e da constituição do ser social. Suas formas sociais orgânicas de produzir (artesanal, manufatureira e industrial - até onde não há controvérsia) são e expressam o movimento de seus próprios criadores - os homens -, suas relações sociais de produção burguesas, no tempo e no espaço ao decomporem o trabalho individual como fonte da vida e constituirem o trabalho social como fundamento da 
existência humana (AUED, 2005, 2005a, 2004, 1999). O segundo pressuposto é a constatação de que a superação do modo de produção capitalista se faz, no presente, a partir de uma nova forma social orgânica de produção, contraditória e transitória que emerge do desenvolvimento das forças produtivas sociais, mas que nada tem em semelhante com a forma da grande indústria (muito menos da manufatura e do artesanato) porque mesmo tendo sido desenvolvida em seu bojo, desta se separou superando-a: provisoriamente a chamamos de "sistema de laboratório" (CAMPANA, 2006).

A proposta de investigação tem como objetivo primordial aprofundar essa tese sobre a constituição e desenvolvimento dessa nova forma material, porém nos termos da educação compreendendo-a como relação social que se faz por meio do modo de produção capitalista como afirmação, negação e superação da própria sociedade que a produz.

Apenas nos últimos 10 anos têm se firmado um conjunto de interpretações ${ }^{34}$ sobre as mudanças no modo como funciona o capitalismo e embora a natureza exata dessas mudanças ainda seja objeto de controvérsias têm em comum, para nós, o fato de que significam algo fundamental: são escrachadas as conseqüências do modo de produção capitalista que até mesmo organismos oficiais internacionais, como, por exemplo, a Unesco, além dos nacionais, têm produzido estatísticas globais preocupantes sobre de pessoas abaixo da linha da pobreza, analfabetismo funcional, concentração de riqueza, população carcerária, etc. - claro que com o intuito de fomentar estratégias para dirimir a ameaça sobre a ordem burguesa. Esse cenário conduz pensadores de nossa época como Erich Hobsbawn, Giovanni Arrighi e a István Mészáros a um balanço bastante pessimista, embora reconheçam a possibilidade e a necessidade de alternativas de um novo tipo, onde o socialismo continua em pauta (KUENZER, 1998).

Portanto e partindo deste pressuposto, de que é possível apreender a lógica, senão a necessidade desta transição, buscamos aprofundar o entendimento sobre 0 movimento do modo como os homens unidos pela materialidade produzem para termos uma idéia do curso e das implicações prováveis da revolução em andamento nas (e pelas) forças produtivas sociais para o âmbito da educação, pois, como já disse 
Mészáros (2005), para que esta possa ser outra coisa que não a interiorização das condições de legitimidade do sistema é preciso que se descubra sua relação com o trabalho e com a alienação.

Conforme Aued (2004), os que vêm estudando as formulações de Karl Marx, deparam-se com algumas facilidades principalmente as contidas em O Capital referentes às transformações históricas decorrentes da forma de os homens produzirem sua existência na sociedade burguesa. O guia para a busca de respostas às nossas indagações é a dialética materialista que explicita os nexos e as mediações de uma forma de produção para outra.

Para além das facilidades apreendidas na obra de Karl Marx, dificuldades nos têm sido criadas principalmente pela complexidade dos fenômenos atuais. Considerando a nova base produtiva laboratorial estaremos diante de uma nova prática pedagógica, correspondente? Será esta emancipatória?

A dificuldade se amplifica porque hegemonicamente - passando por uma ressignificação liberal ou neoliberal e pós-moderna - é tido como certo que há um novo princípio educacional no campo das concepções e das políticas o qual eleva a educação como um dos pilares para uma nova sociedade. ${ }^{35}$ Contra-hegemonicamente, um conjunto de pensadores da educação, pertencentes à teoria crítica - como Demerval Saviani, Acácia Z. Kuenzer, Gaudêncio Frigotto, Paolo Nosella, Anton S. Makarenko, Pistrak, Mario A. Manacorda e Mariano F. Enguita, dentre outros - enfatiza a existência de uma nova proposta pedagógica voltada para a construção do que tem sido chamada de "nova subjetividade", que articula as capacidades de agir intelectualmente e pensar produtivamente" (KUENZER, 1998, p.73). Seu ponto de partida é articular o trabalho como princípio educativo para, sem semelhança a qualquer forma de utopismo educacional, pensar a tarefa educacional como transcendência positiva da alienação (MÉSZÁROS, 2006, 2005). ${ }^{36}$

Donde emerge o paradoxo de que uma nova base material do vir-a-ser está se constituindo e se desenvolvendo - se impondo aos homens férreamente -, mas que uma prática pedagógica emancipatória - ou "educação emancipatória", diria Mészáros (2005) - ainda não se explicita, pois a marca do nosso tempo tem sido a impossibilidade 
de os homens produzirem a vida sob as relações burguesas sem, contudo, poderem voltar ao que foram e sem saberem o que serão no futuro (AUED, 2002).

Com tudo isto, a questão que se apresenta é saber se há evidência da constituição e desenvolvimento de uma prática pedagógica relacionada à base produtiva laboratorial que expresse a negação e a superação da prática pedagógica anterior correspondente à base industrial - chamada por Saviani, (2007), de pedagogia tecnicista. Se assim for, nos defrontamos com duas possibilidades teóricas. Uma delas é a de que essa nova prática pedagógica significa uma nova relação social. A outra é que essa nova prática pedagógica corresponde à degeneração da relação social de produção burguesa. Outra formulação possível é que ambas podem estar ocorrendo simultaneamente como realidade burguesa.

Assim, a primeira questão a ser investigada é em que medida o sistema de laboratório apresenta elementos que podem ser considerados o de uma nova prática pedagógica. A segunda é analisar essas relações sociais, engendradas pelo sistema de laboratório.

Para efeito dessa pesquisa, essas considerações nos remetem a duas indagações: não há ou há uma nova prática pedagógica que se manifesta na nova forma produtiva laboratorial? Se estamos diante de uma nova prática pedagógica que (se) constitui e desenvolve (n)o e pelo sistema de laboratório, será ela afirmadora ou degenerativa da sociedade burguesa? Destarte é que indagamos se essa nova prática pedagógica traz em seu bojo relações que podem se constituir em superiores às capitalistas.

Em termos de objetivos a possibilidade de pesquisa à área da Educação se expõe nos termos a seguir. No aspecto geral, o objetivo seria desvelar e analisar as relações sociais, correspondentes à prática educativa, advinda da forma produtiva de base laboratorial, buscando apreender, nesta materialidade, os elementos de superação da relação burguesa e a possibilidade de uma prática pedagógica emancipadora. No aspecto específico seria preciso: 1) aprofundar a análise do processo de produção de base laboratorial, 2) apreender e analisar as relações sociais correspondentes à prática pedagógica engendradas por essa forma produtiva e 3) analisar se esta forma produtiva e a prática pedagógica que lhe corresponde são 
manifestações da degeneração da sociedade burguesa ou indícios do surgimento de uma sociedade vir-a-ser.

O procedimento metodológico a ser adotado é o de desvelar a prática pedagógica existente na materialidade capitalista, admitindo o existente como a força produtiva materializada na máquina-ferramenta-automática de precisão quântica, tendo como pressuposto que o processo histórico da produção material dos homens se configura pela transmutação da tese para a antítese e desta para a síntese.

Para o primeiro objetivo específico, pretende-se aprofundar o conteúdo desenvolvido a respeito da produção laboratorial, nesse artigo tratado no item 1, e realizado um levantamento da bibliografia de conteúdo marxista produzida por pensadores da educação consoantes com a temática das forças produtivas. Em seguida, há que se efetivar a comparação entre a produção laboratorial e a existência uma nova prática pedagógica para diagnosticar uma simetria, se houver.

Para o segundo objetivo específico, seria bastante útil uma pesquisa etnográfica no Laboratório Nacional de Luz Síncrotron (LNLS), localizado na cidade de Campinas-SP, para confirmar, negar ou transformar a simetria anteriormente perquirida. Ele é operado pela Associação Brasileira de Tecnologia de Luz Síncrotron (ABTLuS) mediante um Contrato de Gestão assinado com o Conselho Nacional de Desenvolvimento Científico e Tecnológico (CNPq) e o Ministério da Ciência e Tecnologia (MCT). Assim, quando há propriedade intelectual envolvida, há uma taxa para o uso dos experimentos. Trata-se de uma das instituições que ocupam o Pólo II de Alta Tecnologia de Campinas (região onde estão, por exemplo, a UNICAMP, a PUCCampinas, a Fundação CNPq) da área de telecomunicações e empresas de base tecnológica.

No LNLS, desde 1997, funciona a única fonte de luz síncrotron existente em todo o hemisfério Sul a qual permite estudar os ingredientes básicos dos materiais, os átomos e as moléculas - são apenas 14 países que têm laboratórios síncrotron. Este equipamento foi desenvolvido, construído e é operado inteiramente por brasileiros. Além dele, existem outros equipamentos relacionados a um centro de microscopia eletrônica: três microscópios e todos os equipamentos necessários para preparar amostras de materiais a serem estudados. Também, é no LNLS que está hoje o 
microscópio mais potente da América Latina, capaz de ampliar um objeto em 1 milhão e meia de vezes - neste caso, os equipamentos podem ser usados por pesquisadores externos. Outro laboratório de ressonância magnética nuclear com dois espectrômetros também é aberto para usuários bem como vários laboratórios de apoio.

O orçamento anual do LNLS, aprovado pelo Congresso Nacional (em 2002) para 2003 foi de 28,145 milhões $^{37}$ (sendo o orçamento anual de todo o Ministério da Ciência e Tecnologia no mesmo ano, de 2,14 bilhões de reais). Isto incluiu o pagamento de pessoal, recursos para a manutenção e novos desenvolvimentos tecnológicos. A equipe fixa tem 180 pessoas. Outras 80 integram a equipe como bolsistas e estagiários. E $90 \%$ dos cientistas (físicos, químicos, biólogos, engenheiros de materiais) que usam o LNLS são de outras instituições. Eles podem ser de uma universidade ou de um outro centro de pesquisa, do Brasil ou do Exterior, ou da indústria. Após passar alguns dias em Campinas, onde fica o LNLS, para fazerem as experiências necessárias em uma das estações experimentais instaladas na fonte de luz síncrotron ou outros equipamentos disponíveis, retornam a seus locais de origem, onde analisam todas as informações obtidas.

A intenção da incursão etnográfica a este local é a idéia de estabelecer a correspondência entre as forças produtivas sociais e as relações sociais de produção, especificamente, relacionadas à prática pedagógica, tendo por base a afirmação de Marx de que o moinho pelo braço nos dá a sociedade feudal; o moinho a vapor, a sociedade capitalista. Buscaremos responder à pergunta: o que o "moinho atômico" produz? Para elucidação desta resposta é imprescindível o diálogo com as teorias sociais/educacionais contemporâneas de conteúdo marxista.

Finalmente, para o terceiro objetivo específico, se adotaria a análise histórica e teórica das informações até então desenvolvidas, tendo por base o processo de emancipação universal humana contida na obra de Karl Marx e a prática pedagógica emancipatória contida em autores marxistas contemporâneos. Também seriam utilizadas, conforme Aued (2004), as formulações apresentadas por Marx no que concerne aos elementos da sociedade vir-a-ser, explicitadas ou engendradas como potencialidade pela sociedade burguesa, e as compararemos com os elementos por nós apreendidos como nova força produtiva do trabalho social. 
A formulação e explicitação de cada um dos objetivos específicos sob a forma de três artigos e a junção de seus conteúdos seriam capazes de evidenciar e destacar os nexos e as mediações entre a força produtiva do trabalho social engendrado pelo capitalismo na atualidade (à qual estamos chamando de "sistema de laboratório") e as relações sociais de produção, especificamente as práticas pedagógicas, bem como a possibilidade histórica de uma outra sociedade mediante uma nova prática pedagógica que emerge das entranhas do modo de produção capitalista?

\section{CONCLUSÕES}

Ratificamos, e não discordamos, que as relações sociais estão intimamente ligadas às forças produtivas, pois, adquirindo novas forças produtivas, os homens transformam o seu modo de produção e todas as suas relações sociais, e que, nesse contínuo, de imutável só existe a abstração do movimento. Entretanto chamamos a atenção para o caráter material orgânico e processual dos homens se fazerem produtos deles mesmos, ao se unirem para produzir socialmente os seus meios de produção, no momento histórico em que seu ser social se caracteriza pela apropriação do produto do trabalho alheio, na troca, sem que para isso se entregue ao outro uma quantidade correspondente (equivalente) de produto de trabalho na circulação da riqueza. Vimos que o que os homens produzem, muito mais do que "forças produtivas", e o modo como produzem, muito mais do que "relações sociais", é essencialmente a relação entre os homens, $\mathrm{H}-\mathrm{H}$, como vir-a-ser social. Com isso, pensamos escapar da dogmatização da assertativa de que o movimento da história é dado pelo movimento das forças produtivas, que coloca os esforços de Marx do ponto de vista de uma lei geral do desenvolvimento tecnológico, ou de sua vinculação aos "progressos" das forças produtivas. Entendemos que estar atento ao discurso do progresso não significa que não seja preciso estar atento ao desenvolvimento das forças humanas e omitir 0 domínio humano sobre suas condições de trabalho e suas transformações.

Adotamos como pressupostos da produção atual a criação dos homens que nos procederam, despojando-os de seu caráter natural e submetendo-os ao poder dos 
indivíduos unidos. Evidenciamos as condições criadas pelos homens, através da produção e do intercâmbio anteriores, como condições inorgânicas, mas sem imaginar que gerações precedentes tinham como plano ou como destino fornecer-lhes materiais e sem crer que essas condições fossem inorgânicas para os indivíduos ("como pessoas" e não naquilo que têm de acidental) que a criaram.

Nosso ponto de partida real não é nem grande indústria nem a ciência conscientemente aplicada do final do século XIX, mas a do final do século XX/início do século XXI. E é esta ciência atual que remodela à sua produção as formas da grande indústria, manufatureiras e artesanais. A ciência, atualmente, vista como decomposição da matéria mesma em partículas quânticas é a própria decomposição do objeto de trabalho em si e para si e se origina da decomposição dos instrumentos de trabalho, realizada pela grande indústria, cujo ponto de partida foi a máquina-ferramentaautomática. Portanto, temos que a grande indústria hoje se transmuta, ao ser determinada pelo sistema de laboratório, passando a integrar uma nova totalidade: antes, foi engendrada pela manufatura, que alterava a forma exterior dos objetos, e agora é a parte operacional do sistema de laboratório alterando a forma exterior dos objetos a partir da constituição atômica da matéria.

Distintamente do modo como a objetividade do trabalho se materializa nas fases manufatureira e industrial, na fase laboratorial a objetividade do trabalho tem como ponto de partida os elementos constitutivos da matéria - do objeto sobre o qual se trabalha - e se materializa em um instrumento de trabalho, a máquina-ferramentaautomática de precisão quântica, cuja característica determina a universalização do conhecimento (general intellect) dos homens na produção e na criação das mercadorias.

A máquina-ferramenta-automática de precisão quântica é um sistema que, ao Ihe ser transmitidas força motriz e transmissão apropriadas, age, baseado em princípios quânticos, sobre o objeto, a partir do conhecimento de sua estrutura atômica, molecular. Nesse sentido, a interação entre as várias áreas da ciência se exprime de duas maneiras: a) no sistema de máquinas automáticas, sintetizado num só aparelho e b) na interação de múltiplos sistemas de máquinas automáticas, materializada em vários aparelhos que atuam conjuntamente. 
No primeiro modo de interação, cada aparelho é a síntese diminuta da "combinação de máquinas de diferentes espécies e diferentes habilidades dos homens" - ou, do "verdadeiro sistema de máquinas", conforme Marx (1996, p.432) -, que opera sobre o objeto. Abstraindo a interação dos aparelhos entre si, observando um aparelho isoladamente, a transformação que se opera sobre o objeto é desprovida de caráter subjetivo. Pelo aparelho, a execução é objetiva em si mesma, por meio dos seus diversos componentes, e o problema de levar a cabo cada um dos diversos processos e de entrelaçá-los é resolvido com a aplicação de outros domínios da ciência. Parece que executa, nesse caso, todos os movimentos necessários para a transformação "sem ajuda humana", pois a intervenção humana (que requer habilidades específicas) ocorre em função da vigília e/ou término da vigília sobre o processo. Entretanto, o ser social, o humano, está expressado/materializado no aparelho.

No segundo modo de interação, o conjunto dos vários aparelhos (cada qual constituindo um sistema de máquinas diminuto), acrescidas as habilidades dos homens vivos para, teleologicamente, decomporem partículas quânticas, em si e para si, constituem o sistema de laboratório. Não são os aparelhos, isoladamente, que constituem seu elemento fundante, mas os vários aparelhos existentes conjuntamente com as habilidades pensantes dos homens. A cooperação entre os homens não ocorre sob a forma de combinação de um único sistema de máquina-ferramenta-automática parcial complementar, tal qual na grande indústria (que patenteia o "verdadeiro sistema de máquinas") em que as máquinas controlavam os homens, predominantemente ao controle destes sobre elas. A cooperação ocorre sob a forma da combinação de vários sistemas de máquinas-ferramenta-automáticas, expressados na existência dos vários aparelhos. Desse modo, os aparelhos específicos e as habilidades (ambos provenientes de outros domínios) se transformam em órgãos adequados de uma função especial: cada um dos vários sistemas de laboratórios se distingue, pela configuração particular dos vários aparelhos existentes, para responder a uma necessidade bem definida.

Sendo assim, o caráter geral material do processo se expressa no e pelo general intellect, como força universal pensante, porque sendo os processos parciais (realizados pelos aparelhos) que o constituem examinados objetivamente em si mesmo, 
a universalidade como objetivação se expressa não somente nos aparelhos, mas também - e fundamentalmente -, materialmente, no homem pensante, teleologicamente posto. Nesse sentido, o general intellect, posto pelo sistema de laboratório, é pura ação humana intelectual, consciente e objetivamente posta, porque tem por pressuposto a decomposição do trabalhador coletivo materializado na máquina, cujo resultado são os aparelhos de laboratório que decompõem a matéria. Nisso reside o caráter revolucionário/salto ontológico deste processo de produzir.

Para além de encurtar a parte do dia de trabalho da qual o trabalhador precisa para si mesmo, o trabalhador social engendra o pressuposto material de superação da própria alienação ao criar a máquina-ferramenta-automática que decompõe partículas quânticas (que constitui o aparelho do sistema de laboratório). Isso porque o material orgânico do ser social, como corpo do homem, é o mesmo da natureza. O sistema de laboratório evidencia que o homem altera/produz sua natureza, ao produzir a natureza externa. Entretanto, a alienação ainda não se resolve por completo, pois os homens ainda não produzem outros homens, em si e para si, mas enquanto exterioridade que é capital. Cada aparelho opera sobre determinado objeto fornecendo matéria-prima a outro aparelho. Tais aparelhos não necessariamente funcionam de forma simultânea, de modo que o produto se encontre simultaneamente em todas as fases de transição (o mesmo não se pode dizer da produção laboratorial industrial, que fornece elementos ao sistema de laboratório). Por isso, a cooperação entre os homens, no sistema de laboratório, não estabelece proporções quantitativas entre setores especializados, com referência ao número ou velocidade dos aparelhos, mas qualitativas referentes a funções dentro da equipe que podem ou não estar vinculadas a algum tipo de aparelho: "são especificações técnicas e avaliativas de crédito dos indivíduos, socialmente requeridas" (LATOUR, 1997). O general intellect se objetiva no homem. A continuidade dos processos parciais, os quais são efetivados objetivamente por aparelhos, é um princípio fixado pela universalidade do processo social de produção dado, nesse caso, pelo general intellect nos homens objetivados. Note-se que a força engendrada socialmente pelos homens em cooperação adveio de um processo historicamente determinado e que expressa a criação universal entre todos os homens na produção material de sua existência (AUED, 2004). Nesse sentido, 
à medida que os aparelhos se universalizam em todos os campos, a divisão do trabalho nas condições burguesas tende a desaparecer.

Observe-se que, na grande indústria, a universalidade objetivada é a interligação, pois o universal é a máquina a qual está seccionada (trata-se de máquinas parciais que vão formar o "sistema de máquinas"). Sendo assim, observamos divisão das máquinas, mas não dos homens, pois estes acompanham as máquinas, as quais modificam formas e criam objetos, só então ocorrendo divisão técnica. Já no sistema de laboratório, o universal é a máquina singular (aparelho) e todos os sistemas de laboratórios de modo a não estar secionado. Logo, pelo pensamento, os homens tendem a serem igualados, pois o que os diferencia é o grau de informação do conhecimento. Por ser essa condição do trabalho pura abstração ela tende a negar a divisão do trabalho, subsumida pela lógica do capital, colocada pela grande indústria. $O$ trabalhador individual direto se vê diante a um novo fetiche no processo de trabalho: pode, aparentemente, controlar e decidir sobre a forma de produzir o conhecimento.

Com tudo isso, pensamos que abre-se à Educação a seguinte questão de pesquisa, qual seja, a de se perquirir - sob a perspectiva da possibilidade do novo e não da reprodução do velho - em que medida há uma nova prática pedagógica, correspondente à atual forma produtiva laboratorial (forma que é superior à da grande indústria e manufatura), que expresse a afirmação, negação e ao mesmo tempo a superação da relação social burguesa de produzir. Entende-se que a resposta a este questionamento traz à tona questões fundantes relacionadas à escola, à relação ensino-aprendizagem, ao currículo, etc., permitindo vislumbrar, a partir de suas condições de atuação dos homens reais, ações de intervenção social.

\section{NOTAS}

${ }_{1}^{1}$ Mestra em Economia pela Universidade Federal de Santa Catarina - UFSC. Doutoranda em Educação pela UFSC. Email: samyacampana@gmail.com

2 “Nano, que significa 'anão' em grego, quer dizer também um bilionésimo. Um nanômetro (1 nm), por exemplo corresponde a um bilionésimo $\left(10^{-9}\right)$ do metro e um nanosegundo corresponde a um bilionésimo do segundo. O diâmetro de um átomo é cerca de $0,2 \mathrm{~nm}$ enquanto o de um fio de cabelo é de aproximadamente $50.000 \mathrm{~nm}$. Já as dimensões típicas de um vírus se encontram na faixa de 5 a $100 \mathrm{~nm}$. O nanomundo abrange desde átomos a objetos com cerca de $100 \mathrm{~nm}$. Esse é o universo da nanociência e da nanotecnologia" (VALADARES, 2005, p.vii). 
3 O microscópio de varredura por efeito túnel (scanning tunnelling microscope, ou SIM), a ferramenta fundamental para a entrada no pequeno mundo, foi "criado" em 1981 pela equipe do laboratório da IBM em Zurique, na Suíça (CARDOSO, 2005).

${ }^{4}$ Às vezes a máquina (por inteiro) da produção automática de precisão atômica e/ou molecular é uma edição mais ou menos modificada da máquina de produção mecânica, como ocorre com o microscópio por exemplo, na forma do microscópio eletrônico de escaneamento (ou transmissão) reconhece-se o microscópio mecânico. Já a forma moderna (o microscópio de precisão atômica e/ou molecular) apresenta modificações substanciais. Outras vezes os princípios clássicos (ou física aplicada) que movimentam os órgãos ativos implantados na armação da máquina-ferramenta automática de precisão atômica e/ou molecular já são conhecidos, como a mecânica, a termodinâmica, eletromagnetismo, ondulatória, ótica e acústica.

5 "Os princípios da física [clássica], tanto quanto podemos perceber, não implicam na impossibilidade de manipular coisas átomo por átomo. Não se trata de uma tentativa de violar quaisquer leis" (FEYNMAN, 1959, p.12).

${ }^{6}$ Diferentemente de Watt, que descreveu em 1784 sua máquina a vapor (a máquina rotativa de ação dupla, um motor que produzia sua própria força motriz consumindo água e carvão com potência inteiramente controlável) como agente geral da indústria mecanizada conforme informação de Marx (1996), a introdução de motores elétricos movidos a derivados do petróleo ocasionou modificações (posteriores) não desprezíveis, entretanto não é considerada por nós como revolucionária uma vez que já estava posto historicamente pela máquina motriz a vapor a existência um motor que produz a própria força com potência inteiramente controlável.

${ }^{7}$ O que levou Born (1969) a afirmar que a física clássica, embora o fundamento a priori da física atômica e da teoria quântica, não era correta em tudo.

${ }^{8}$ Para saber sobre as grandes sínteses da Física ao final do século XIX e sua superação, ver Martins (2005).

${ }^{9}$ Por exemplo, o problema tecnológico do controle da temperatura de fornos metalúrgicos simplesmente não pôde ser entendido dentro do âmbito da Física Clássica, e os físicos começaram a imaginar modelos microscópicos para explicar os fenômenos gasosos formulando a teoria cinética dos gases. Nessa teoria, a temperatura passa a ser uma indicação da energia cinética média das moléculas do gás, sendo possível relacionar o calor específico dos gases à sua composição molecular (MARTINS, 2005). Também as tentativas de explicar o comportamento da radiação utilizando os conhecimentos da mecânica clássica e da termodinâmica não foram bem sucedidas (GROOTE, 2005).

10 Esse modelo consistia de milhares de elétrons que se moviam em um enxame de abelhas numa nuvem desprovida de massa e que possuía carga positiva, de modo que o conjunto fosse eletronicamente neutro.

11 Por meio de interpretações que divergem da física clássica de Newton, o trabalho de Plank engloba os princípios físicos capazes de explicar o comportamento da matéria e da luz em escalas muito pequenas. A descrição quântica de um sistema físico aponta comportamentos contraditórios desse sistema, que variam em função das diferentes condições de observação. O caráter não determinístico do universo, sustentado pela nova teoria, foi reforçado pelo princípio da incerteza, do físico alemão Werner Heisenberg.

12 Uma anedota ilustra bem o ponto de partida do laboratório, o objeto e a não-compreensão por parte dos homens das descobertas em fins do século XIX, momento em que se colocava claramente a importância de instrumentos (máquinas) melhores. "Quando o físico e químico britânico Michael Faraday (1791-1867) demonstrou o fenômeno recém-descoberto da indução eletromagnética, o então ministro 
das finanças da Inglaterra, William Gladstone (1809-1898), teria perguntado ao cientista: 'Está tudo muito bem, mas para que serve a indução eletromagnética?' A resposta de Faraday: 'Eu não sei, mas um dia o senhor poderá cobrar imposto sobre isso'" (RUMJANEK, 2004, p.22).

13 Conforme Latour (1997), que realizou pesquisa etnográfica por dois anos (1975-1977) em um laboratório de neuroendrocrinologia, "pode-se perfeitamente passar sem as pipetas automáticas, mesmo que se perca um pouco de tempo realizando manualmente a operação. Mas se o contador gama quebra, será difícil medir a radioatividade a olho nu! A observação da radioatividade depende totalmente da presença do contador" (LATOUR, 1997, p.62).

${ }^{14}$ Os inscritores (máquinas que transformam a matéria em escrita), as habilidades e máquinas utilizadas vêm de outro domínio. "Uma seqüência de operações e um teste, atualmente banalizados, foram, no passado, objeto de debate e produziram publicações em outro domínio. Os aparelhos e as habilidades de um domínio materializam os resultados finais de debates ou controvérsias ocorridas em outro espaço. Esses resultados entraram no laboratório por meio indireto [...] O inscritor produz inscrições que pode, por sua vez, servir para que se escrevam artigos ou para que se façam intervenções significativas, concebendo aparelhos a partir de teorias pré-estabelecidas. Quando um membro do laboratório [neste caso de bioquímica/neuroendocrinologia], por exemplo, trabalha em um computador, ele recorre, ao mesmo tempo, à potencialidade da eletrônica e da estatística. Um outro que se utiliza do espectrômetro RMN [ressonância magnética nuclear de alta resolução] para controlar a pureza de seus compostos, usa a teoria do spin e os resultados de 20 anos de pesquisa física fundamental. Quando se discute a estrutura especial de um fator de liberação, utilizam-se implicitamente os trabalhos desenvolvidos pela química em geral, há vários decênios. O mesmo acontece quando se realiza um radioimunoteste para procurar uma nova substância: é suficiente o conhecimento de alguns princípios de imunologia e de radioatividade. Todo o progresso realizado em um laboratório está de certa forma ligado ao que se passa nos outros domínios" (LATOUR, 1997, p.63-64). "O laboratório apropria-se do gigantesco potencial produzido por dezenas de outros domínios de pesquisa, tomando emprestado um saber bem instituído e incorporando-o sob a forma de aparelhagem ou de uma seqüência de manipulaccões". [sublinhado nosso] (LATOUR, 1997, p.66)

15 "É evidente que alguns aparelhos têm um papel mais importante do que outros no processo de pesquisa. O vigor de um laboratório não está tanto na posse deste ou daquele aparelho, mas na presença de uma configuração particular de aparelhos especificamente concebidos para responder a uma necessidade bem definida". Assim, por exemplo, a presença de centrifugadores e evaporadores rotativos permite deduzir que a pesquisa é no campo da biologia, porém não se sabe em qual subcampo. "É pela presença de biotestes, de imunotestes, de radioimunotestes, de Colônias de Sephadex e de toda uma gama de espectrômetros que se reconhece a marca da neuroendocrinologia. Em um mesmo lugar, encontra-se reunida toda uma série de inscritores utilizados de formas muito variadas para estudar diferentes subáreas. O espectrômetro de massa, por exemplo, serve para produzir artigos sobre a estrutura de uma substância; as culturas de células servem para estudar a síntese do ADN na biossíntese dessas mesmas substâncias." (LATOUR, 1997, p.62/62-63).

${ }^{16}$ A respeito do controle das máquinas sobre os homens, remetemos o tema a Marx: "quando a divisão do trabalho reaparece na fabrica automática, ela é antes de tudo distribuição de trabalhadores pelas diferentes máquinas especializadas, e das massas de trabalhadores, que não formam grupos específicos, pelas seções da fábrica, em cada uma das quais trabalham em máquinas da mesma espécie, juntas umas das outras, em regime, portanto, de cooperação simples". Há agora conexão entre o trabalhador principal e seus poucos auxiliares. "A distinção essencial ocorre entre trabalhadores que estão realmente ocupados com as máquinas-ferramenta (inclusive alguns trabalhadores que tomam conta da máquina motriz e a alimentam) e seus auxiliares [...]. Entre os auxiliares podem ser incluídos os que alimentam a máquina com o material a ser trabalhado. Ao lado dessas duas classes principais, há um pessoal pouco numeroso, que se ocupa com o controle de toda a maquinaria e a repara continuamente, como os engenheiros, mecânicos, marceneiros, etc. É uma classe de trabalhadores de nível superior, uns possuindo formação científica, outros dominando um ofício; distinguem-se dos 
trabalhadores da fábrica, estando apenas agregados a eles. Sua divisão de trabalho é puramente técnica" (MARX, 1996, p.480/480-481).

17 Cf. p.413-414 de Marx (1996).

18 Quando as máquinas e o sistema de máquinas tornam-se inteligentes, "esses conhecimentos que se encontram dentro das cabeças dos trabalhadores e em parte nas próprias máquinas são distribuições descentralizadas de um todo altamente complexo de saberes científicos, tecnológicos e produtivos que Marx chama de intelecto geral" (PRADO, 2003, p.123).

19 Há uma separação muito clara entre duas zonas do laboratório. Uma está repleta de aparelhos diversos utilizados em diferentes tarefas: corta-se, cose-se, mistura-se, agita-se, marca-se, etc. Outra contém exclusivamente livros, dicionários e artigos, trabalhando-se apenas com material escrito: lê-se, escreve-se, digita-se ao computador. Além disso, os que pertencem à segunda seção, e que não usam jaleco branco, passam longo tempo discutindo com seus colegas, de jaleco branco, da primeira seção. Os "bacharéis" lêem e escrevem sentados à mesa, enquanto os "técnicos", passam a maior parte do tempo ocupados com os aparelhos (LATOUR, 1997, p.37). Tais proporções qualitativas estão além das fronteiras entre os países: no laboratório em questão, estudado por Latour, é mencionado claramente 6 nacionalidades diferentes e 4 tipos de profissionais, de acordo com a função exercida, envolvidos diretamente com a rotina do laboratório (químicos-pesquisadores, "técnicos" - que preparam 0 laboratório, etc.-, secretárias e empregados - que depositam carregamentos, efetuam limpeza, etc.).

20 Pois "[...] Não é mais o trabalhador que intercala o objeto natural modificado como membro intermediário (Mittelglied) entre ele e o objeto. Mas ele intercala o processo natural que ele transforma em um processo industrial como intermediário (Mittel) entre ele e a natureza inorgânica que ele submete (sich bemeistert)" (MARX apud FAUSTO, 2002, p.130).

${ }^{21}$ Ao observarem o surgimento de uma corrente elétrica entre uma ponta finíssima de tungstênio e a superfície de uma amostra de platina, denominado por eles de corrente de tunelamento, "que só pode ser explicada com base na mecânica quântica, uma teoria sobre os fenômenos que ocorrem no diminuto mundo dos objetos com dimensões de átomos e moléculas" (ZANETTE\&CCARIDE, 2000, p.34), os dois pesquisadores acrescentaram a essa ponta um sistema que permitiu a ela se deslocar sobre a amostra estudada, inventando assim o chamado STM. (Op.cit.). "A ponta e o substrato onde se deposita a amostra ficam ligados por um circuito. Aplica-se uma tensão elétrica no circuito e abaixa-se a ponta do microscópio até quase encostar na amostra. É 'quase` imperceptível ao olho humano, pois a distância entre a ponta e a amostra chega a alguns nanômetros. Pois os elétrons, que só deveriam passar da amostra para a ponta se as duas estivessem encostadas, simplesmente pulam pelo ar mesmo - tunelam , fechando o circuito entre a ponta e a amostra, e criando uma corrente com uma voltagem infinitamente pequena, da ordem de alguns nanoampéres [...] Com o microscópio de efeito túnel, passou-se a enxergar os átomos, antes jamais vistos, e, melhor ainda, conseguiu-se manipulá-los. Certo que dizer 'enxergar' átomos chega a ser uma licença poética, pois o que se vê é uma imagem simulada da variação da corrente elétrica. O levantar e abaixar da ponta do microscópio é uma operação que exige precisão muito além do que qualquer mão humana ou mecânica possa alcançar. Esse trabalho é feito pelos cristais piezelétricos, como o quartzo, que se expandem ou encolhem quando recebem tensão elétrica (sim, mexem-se apenas alguns nanômetros). Há três cristais: o do eixo z (que se move para cima e para baixo), o x (para frente e para trás) e o y (para a esquerda e para a direita). Quando a ponta do microscópio começa a varrer a amostra, movendo-se nos eixos x e y, o eixo z fica na mesma. Porém, quando a ponta encontra uma pequena montanha pela frente, ou seja, um átomo mais alto que os outros, a voltagem da corrente elétrica aumenta, pois a distancia em relação à amostra diminui. No modo de operação mais comum, o de voltagem constante, o eixo z deve, portanto, receber uma alteração de tensão, para que se contraia e suspenda a ponta do microscópio de modo a fazer a voltagem retornar ao valor prévio. A variação da tensão do cristal z resulta num gráfico, que é transformado em imagem - está pronta a fotografia dos átomos. Obviamente, o microscópio de efeito túnel só funciona com amostras de 
materiais condutores ou semicondutores; do contrário, não haveria passagem de corrente elétrica". (CARDOSO, 2005, p.2-3)

22 "Hoje, a tecnologia por trás dos SPM permite estudar diretamente forças entre átomos e moléculas em suas mais amplas variações, bem como forças de atrito, elétricas, magnéticas e químicas. O maior impacto dessa tecnologia é possibilitar a observação de estruturas em escala atômica no espaço real. E isso vale tanto para materiais condutores de eletricidade (como no caso do STM) quanto os isolantes elétricos, além de todos os tipos de materiais difíceis de estudar com microscópios eletrônicos. Outra vantagem desse tipo de equipamento é a sua capacidade de operar à temperatura ambiente, na presença de ar, o que reduz consideravelmente seu custo de construção e operação. Há também a possibilidade de repetir várias vezes a experiência nas mesmas condições, pois a amostra, além de não ser danificada pela experiência, dispensa técnicas sofisticadas de preparação prévia". (ZANETTE\&CARIDE, 2000, p.34).

${ }^{23}$ Gerd Binnig "inventou" "[...] uma ponta de microscópio capaz de enxergar qualquer coisa. Ele acoplou à ponta um pequeno fragmento de diamante, que contorna os átomos da amostra exercendo uma pressão pequena o suficiente para não destruí-la. É o microscópio de força atômica (AFM, em inglês). Conforme o fragmento de diamante se move, quando encontra saliências, move-se também a ponta, criando-se então, imagens como no SIM. Mais importante do que ver átomos é a possibilidade de movê-los, um a um. Isso acontece quando se aplica uma tensão elétrica muito forte entre a ponta do microscópio e a amostra - um átomo salta e gruda na ponta. Se a polaridade da corrente for invertida, o átomo volta para baixo com força, ficando encravado naquele ponto" (CARDOSO, 2005, p.4).

24 Para ler mais sobre a importância e as especificidades técnicas de cada aparelho, ver Zanette\&Caride (2000), Valadares (2005).

${ }^{25}$ Para a física clássica - que é expressão ideal da máquina-ferramenta-automática que tem como limite a alteração da forma exterior do objeto, o conhecimento das propriedades físicas macroscopicamente, 0 conhecimento da natureza - "uma partícula tem seu estado bem determinado por sua posição e seu momento (o produto de sua massa por sua velocidade). Com base apenas nessas duas grandezas, é possível prever, em um determinado instante, os resultados de qualquer medida efetuada sobre ela" (DADIDOVICH, 2004, p.24). Sempre se pode supor de acordo com a física clássica (que interpõe fenômenos macroscópicos) a possibilidade de medir um sistema de modo que a perturbação causada seja desprezível (Op.cit.).

26 Donde a importância que Wierner (1954) atribui a Bolzmann e Gibbs, "mais do que a Einstein, Heisenberg ou Planck, à primeira grande revolução da Física do século XX" (WIERNER, 1954, p.12). Bolzmann e Gibbs introduziram "[...] a estatística na Física de maneira muito mais completa, de sorte que a abordagem estatística se tornou tão válida não apenas para sistemas de enorme complexidade, mas inclusive para sistemas tão simples quanto o de uma única partícula num campo de força". "A estatística", continua Wierner, "é a ciência da distribuição, e a distribuição tencionada por esses cientistas modernos não dizia respeito a grande número de partículas similares, mas às várias posições e velocidades a partir das quais um sistema físico poderia ter início. Por outras palavras: no sistema newtoniano, as mesmas leis físicas se aplicavam a uma multiplicidade de sistemas que se iniciavam a partir de uma multiplicidade de posições e momentos. Os novos estatistas lançaram inédita luz sobre este ponto de vista. Mantiveram, na verdade, o princípio segundo o qual se poderiam distinguir certos sistemas de outros pela sua energia total, mas rejeitaram a suposição de que sistemas com a mesma energia total pudessem ser distinguidos com nitidez, indefinidamente, e descritos para sempre por meio de leis causais" (WIERNER, 1954, p.10).

${ }^{27}$ Esses equipamentos passaram a usar feixes de partículas cujo comprimento de onda é menor do que o da luz visível, passando a ser denominado SEM (sigla, em inglês, para microscópio de escaneamento) ou TEM (microscópio eletrônico de transmissão) (ZANETTE\&CARIDE, 2000). 
28 "Desde que o pesquisador americano Don G. Eigler, do laboratório da IBM na Califórnia, nos Estados Unidos, alinhou átomos de xenônio para escrever o logotipo da empresa sobre uma superfície de níquel, começou urna verdadeira corrida entre os cientistas para conseguir o melhor domínio da técnica de arrancar átomos de um ponto e colocá-los em outro" (CARDOSO, 2004, p.4). No que diz respeito aos sistemas de laboratório da química e da biologia, o avanço para a nanotecnologia não partiu desses domínios, embora o pareça, porque "a nanociência e a nanotecnologia dedicam-se a desvendar essas novas propriedades e a explorar as suas múltiplas aplicações tecnológicas. É importante ressaltar, todavia, que, além dos tamanhos dos objetos, o que define a nanociência e a nanotecnologia são os novos procedimentos utilizados para se investigar o nanomundo. $O$ estudo e a utilização de objetos nanométricos vêm de longa data. Os químicos, por exemplo, há muito estudam como os átomos se juntam para formar moléculas. Deste modo, a química deveria ser incorporada, pelo menos em partem à nanociência. $\mathrm{O}$ mesmo poderia ser dito em relação à biologia, uma vez que os organismos vivos são formados a partir de objetos nanométricos, ou seja, a partir de moléculas complexas ou de arranjos ainda mais complexos dessas moléculas. A nanoquímica vai muito além dos procedimentos tradicionais adotados pelos químicos para sintetizar compostos, como misturar, agitar, aquecer, filtrar, destilar, etc. Os químicos, além desses métodos, utilizam agora técnicas mais elaboradas. Inicialmente uma molécula é projetada. Para fabricá-la, são utilizados métodos que envolvem manipulação da matéria na escala atômica, não raro em ambiente de ultra-alto vácuo. Para que a molécula adquira as propriedades desejadas, um novo átomo ou conjunto de átomos ligados deve ser adicionado em um ponto predeterminado da molécula. É como se os químicos brincassem de lego, com a diferença de que as peças básicas agora são átomos e moléculas. Enfim, o que caracteriza tanto a nanociência quanto a nanotecnologia é a adoção de técnicas que permitem tanto visualizar como manipular a matéria na escala nanométrica, incluindo a manipulação direta de átomos". [sublinhado nosso] (VALADARES, 2005, p.53).

29 São estruturas nanométricas de átomos de carbono rearranjadas pelos homens. Os nanotubos são folhas de grafite que se enrolam para formar tubos com diâmetro variando entre 2 e $5 \mathrm{~nm}$; apresentam várias propriedades inéditas, a começar pela resistência mecânica. Eles permitem fabricar sólidos quatro vezes mais leves e pelo menos cinco vezes mais resistentes que o aço gerando aplicações relevantes para a indústria mecânica. (VALADARES, 2005). Possuem propriedades elétricas podendo atuar com característica semicondutora, condutora e até supercondutora, e condutividade térmica.

${ }^{30}$ Moléculas aplicadas em drug delivery, portando outras moléculas por auto-organização hierárquica, o que permite a limpeza de ambientes através do aprisionamento de íons metálicos.

${ }^{31}$ A exemplo, ver o anexo1 - que traz o quadro sobre as redes identificadas e os laboratórios existentes no Brasil - do seguinte documento: MCT, Proposta do GT criado pela portaria do MCT no 252 como subsídio ao Programa de desenvolvimento da nanociência e da nanotecnologia do PPA 2004-2007.

32 A exemplo, "o que atualmente limita a possibilidade de utilização de células solares em grande escala é seu custo de fabricação e seu rendimento, dois problemas que a nanotecnologia deverá estar em condições de resolver sem dificuldade". (LEVY, 2000, p.14).

33 Em 2004, o orçamento para desenvolvimento da área de nanociência e nanotecnologia prevê investimentos oficiais de $\mathrm{R} \$ 8,7$ milhões. Até 2007, segundo o PPA, esses investimentos devem totalizar quase $\mathrm{R} \$ 80$ milhões. É pouco, quando comparamos os investimentos realizados por países desenvolvidos nesse segmento. Os Estados Unidos, por exemplo, investiram algo em torno de US $\$ 1,5$ bilhão no ano passado nessa área, sendo US\$ 900 milhões do governo e US\$600 milhões da iniciativa privada (BRAZIL, 2004, p.4).

34 Uma sistematização é feita por Martins (2003) dentre as perspectivas: globalista, da hegemonia compartilhada, neodesenvolvimentista, do sistema mundial, da teoria da dependência em sua versão marxista. 
35 Algumas das produções vinculadas à Unesco, por exemplo, são Braslavsky (2003, 2005), Campbell (2002), Carnoy (2003), Delors (2006), Diskin (2002), Morin (2000, 2003), Noleto (2004), Werthein (2000, 2004).

${ }^{36}$ Esse conjunto se impõe à tarefa de a) superar o poder ilusório da educação (que caracteriza as teorias não-críticas) bem como a sua impotência (decorrente das teorias crítico-reprodutivistas) e b) colocar nas mãos dos educadores uma arma capaz de permitir-lhes o exercício de um poder real, ainda que limitado (SAVIANI, 2005).

${ }^{36}$ Deste valor, $\mathrm{R} \$ 18$ milhões sob contrato com o Ministério da Ciência e Tecnologia.

\section{REFERÊNCIAS BIBLIOGRÁFICAS}

AUED, Idaleto Malvezzi. Transcendência (aufhebung), alienação, manufatura e maquinaria em Karl Marx; ou de como o homem supera sua desumanização e faz-se homem plenamente desenvolvido. 2005. 56f. Tese de Pós-Doutorado. Programa de Pós-graduação em Sociologia, Unesp, jun-2005a. (Texto Inédito).

Alienação, maquinaria e grande indústria moderna em Karl Marx: ou de como o homem se liberta do trabalhador. 2005. 44f. Tese de Pós-Doutorado. Programa de Pósgraduação em Sociologia, Unesp, mar-2005b. (Texto Inédito).

Alienação, divisão do trabalho e manufatura em Karl Marx: ou de como libertar o trabalhador do trabalho. 2004. 59f. Tese de Pós-Doutorado. Programa de Pósgraduação em Sociologia, Unesp, dez-2004. (Texto Inédito).

Marxismo e Geografia. In: ALBA, Rosa S., OTSUSHI, Cristina e ZIBORDI, Antônio F.G. (orgs.) O ensino da Geografia no novo milênio. Chapecó, SC: Argos, p.13-58, 2002.

Capital e emancipação humana: o ser social. In: AUED, Bernadete W. (Org.). Educação para o (des) emprego: ou quando estar liberto da necessidade emprego é um tormento. Petrópolis, RJ: Vozes, p.109-131,1999.

BRASLAVKY, Cecília et alii. Dez fatores para uma educação de qualidade para todos no século XXI. São Paulo: Moderna, 2005.

Aprender a viver juntos: educação para a integração na diversidade. Brasília, Unesco, IBE, 2003.

BORN M., AUGER P., SCHRÖDINGER E., HEISENBERG W. Problemas da Física Moderna, Ed. Perspectiva, São Paulo, 1969. 
BRAZIL, Carlos. O que é, como evoluiu e em que dimensão se encontra a nanotecnologia. [Documento eletrônico] 8/10/2004, p.1-5. Disponível em < http://www.universia.com.br/materia >. Acesso em 16 julho 72005.

CAMPANA, Samya. A emancipação humana a partir da síntese histórica do desenvolvimento das forças produtivas sociais: o sistema de laboratório. 2006. $256 f$. Dissertação (Mestrado em Economia) - Programa de Pós-Graduação em Economia, UFSC, 2006.

CAMPBELL, Jack (org.). Construindo um futuro comum: educação para a integração na diversidade. Brasília, Unesco, 2002.

CARDOSO, Fátima. Nanotecnologia: a arte de montar matéria átomo por átomo. Mar/2005 [Documento eletrônico]. Disponível em < http://www.geocities.com/capacanaveral > Acesso em 13 julho 2005.

CARNOY, Martin. Mundialização e reforma da educação: o que os planejadores devem saber. $2^{\underline{a}}$ ed. Brasília, DF: Unesco, 2003.

DADIDOVICH, Luiz. Informação quântica: do teletransporte ao computador. In: Revista Ciência Hoje. v.35, n.206, p.24-29, jul-2004.

DELORS, Jacques et alii. Educação: um tesouro a descobrir - relatório para a Unesco da comissão internacional sobre educação para o século XXI. 10ª ed. São Paulo: Cortez, 2006.

DISKIN, Lia; ROIZMAN, Laura G. Paz, como se faz? Semeando a cultura de paz nas escolas. Brasília: Unesco, 2002.

ESTAÇÃO CIÊNCIA. A Energia e as Transformações Químicas: a combustão química. In: Estação Ciência: Exposições apresentadas na Eciência. USP.pp.4 [Documento eletrônico]. Disponível em < http://www.eciencia.usp.br/exposição > . Acesso em 26 julho 2005.

FAUSTO, Ruy. Marx: lógica e política. Livro III. São Paulo: Ed.34, 2002.

FERRAZ NETO, Luiz. Primeiros Passos da Física Moderna. sd, p.1-3. [Documento eletrônico]. In: Primeiros Passos: evolução das idéias. Disponível em < http://www.feiradeciencias.com.br > Acesso em 05 agosto 2005.

FEYNMAN, Richard. Há muito espaço lá embaixo: um convite para penetrar em um novo campo da física. 1959. [Documento eletrônico]. In: ComCiência Nanotecnologia\&Nanociência. n.37, nov., 2002. Disponível em < http://www.comciencia.br > Acesso em 16 julho 2005. 
GROOTE, Jean-Jaques. Max Planck e o início da Teoria Quântica. [Documento eletrônico] In: ComCiência - Física Moderna: mito e ciência. n.20, mai., 2001. Disponível em < http://www.comciencia.br > Acesso em 05 agosto 2005.

KUENZER, Acácia Zeneida Desafios teórico-metodológicos da relação trabalhoeducação e o papel social da escola. In: FRIGOTTO, Gaudêncio (org.). Educação e crise do trabalho: perspectivas de final de século. Petrópolis: Vozes, p. 5-75, 1998.

LATOUR, Bruno, WOOLGAR, Steve. A vida de Laboratório: a produção dos fatos científicos. Rio de Janeiro: Relume Dumará, 1997.

LEVY, Frederic. Introdução à nanotecnologia molecular. [Documento eletrônico] Conferência proferida na Academie Interdisciplinaire des Sciences de Paris (AISP). Disponível em < http://supertrunfonet.tripod.com/trunfonticiadofuturo/id3.html $>$ Acesso em 12 julho 2005

MARTINS, Roberto de Andrade. Física e História. In: Revista da Sociedade Brasileira para o progresso da ciência. Edição Ciência e Cultura - temas e tendências: Física. Ano 57, n.3, p.1-8, jul-ago-set. 2005.

MARX, Karl. Manuscritos econômico-filosóficos. Trad. Jesus Ranieri. São Paulo: Boitempo, 2004.

O Capital: o processo de produção do capital. Livro I, v.1, 15ª ed. - Rio de Janeiro: Bertrand Brasil, 1996. 1987.

Teorias da Mais-Valia. Livro Quarto, v.1. $2^{\underline{a}}$ ed. Rio de Janeiro: Bertrand Brasil,

MEES, C. E. Kenneth. The Organization of Industrial Scientific Research. New York, McGraw-Hill Book Co., 1920. [Documento eletrônico]. Disponível em < http://www.inovacao.unicamp.br/report/inte-kodak.shtml > Acesso em 12 julho 2005.

MÉSZÁROS, István. A alienação e a crise da educação. In: . A teoria da alienação em Marx. São Paulo: Boitempo Editorial, 2006.

A educação para além do capital. São Paulo: Boitempo Editorial, 2005.

MORIN, Edgar. Os sete saberes necessários à educação do futuro. Editora Cortez: São Paulo, 2000.

MORIN, Edgar; CIURANA, Emilio Roger; MOTTA, Raúl Domingo. Educar na era planetária: o pensamento complexo como método de aprendizagem pelo erro e incerteza humana. São Paulo: Cortez, 2003. 
NOLETO, Marlova Jovchelovitch, et alii. Abrindo espaços: educação e cultura para a paz. 3를 ed. Brasília: Unesco, 2004.

PRADO, Eleutério. Pós-grande indústria: trabalho imaterial e fetichismo - uma crítica a A.Negri e M.Hardt. In: Revista Crítica Marxista. n.17, p.109-130, nov.2003.

RUMJANEK, Franklin. Fronteiras da ciência: ética e desenvolvimento. In: Ciência Hoje, v.35, n.206, p.22-23, jul-2004.

SAVIANI, Demerval. História das idéias pedagógicas no Brasil. Campina, SP: Autores Associados, 2007. (Coleção memória da educação).

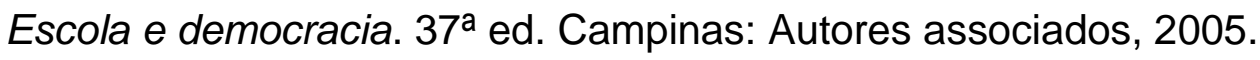

THEIS, Thomas. La inmensidad de lo mínimo: breve introducción a las tecnologías de nano escala. [Documento eletrônico] In: GRUPO ETC., Washington Post, 22 de febrero de 2004. jun.2004. Disponível em < www.etcgroup.org >. Acesso em 10 março 2005.

TOMA, Enrique E. Química e Nanotecnologia: é hora de despertar! In: Informativo $C R Q-I V$ : Nanotecnologia. Edição de jan-fev-2005. [Documento eletrônico]. Disponível em < www.cra4.org.br/informativo/fevereiro 2005 >. Acesso 3 maio 2005.

VALADARES, Eduardo de Campos. Aplicações da Física quântica: do transistor à nanotecnologia. 1ㄹed. São Paulo: Editora Livraria da Física, 2005. (Temas atuais de física).

WERTHEIN, Jorge; CUNHA, Célio da. Educação e conhecimento: a experiência dos que avançaram. Brasília, DF: Unesco, 2004.

Fundamentos da nova educação. Brasília: Unesco, 2000.

WIERNER, Norbert. Cibernética e Sociedade: o uso de seres humanos. São Paulo: Cultrix, 1954.

ZANETTE, Susana Isabel, CARIDE, Aníbal Omar. As novas imagens da matéria. In: Revista Ciência Hoje. v.27, n.132, p.32-38, jul-2000. 